\title{
Experimental Studies on the Indican Formation.
}

First Report.

By

\section{Dr. YOSHIO KISHI.}

(岸少男)

(From the Institute of Forensic Medicine, Toholu Imperial

University, Sendai. Director: Prof. Dr. T. Ishikawa.)

CONTENTs.

I. Introduction.

II. Matters concerning the experiments.

III. Methods.

1. Determination of indican in urine and blood.

2. Determination of total amount of blood and blood-plasma in the animal body.

3. Determination of the anount of hemoglobin.

IV. Experimental.

1. The influence of diet on the indican formation.

2. The influence of inanition on the indican formation.

8. The infuence of parenteral introduced liver or kidney cells on the indican formation.

4. What changes in the amount of indican take place in nephritis?

a. In uran nephritis.

b. In nephritis due to habu-poison.

5. The intluence of the discharge of feces by means of laxative on the indican formation.

V. Discussion.

V1. Summary.

\section{INTRODUCTION.}

At present there are two theories concerning the formation of indican in organisms; one adovocates that indican is generated by putrefaction of protein in the digestive tube, while the other persists that it is formed as an intermediate product by metabolism in the body. The two theories conflict with each other and do not come to one accord. 
First I will give the outline of this discussion on the indican formation, and let it be the introduction of this thesis.

The name Indican was generally established by an Englishman, Schunk, in 1858, when he obtained it as a blue powder from blue urine and discovered that it was identical with indigo. But that indican rcally became the subject of inquiry was only since 1870 , when $J$ affe's studies ${ }^{1}$ on this problem were given out. Even in those days there were already many conflicting opinions about the indican formation. That the indol produced by the action of putrefacting bacteria is one of the sources of indican was proved by Jaffe, yet it was open to question whether there might be other sources or not. Salkowski's experiment ${ }^{3}$ with dogs, in which he found that indican never disappeared in the huuger state, and Hoppe-Seyler's experiment, by which he proved that indol was formed from muscular fibres without the help of bacteria were the powerful ground of the argument on the side of the abacterial formation of indican. But the view that indican never disappears even in the hunger state was opposed by Müller and Nencki, ${ }^{6}$ who asserted that the increased indican in the hunger state was due to the putrefaction of mucin of the intestinal mueosa or to the putrefaction of pancreatic juice and not due to the decomposition of body protein. Hoppe-Seyler's contention was opposed by Kühne because of the defective means of his experiment. Baumann, Harley and Goodbody $y^{s}$ maintained the theory of bacterial formation of indican and claimed that indican disappeared when putrefaction in the intestinal canal was prevented by disinfectant. Thus contentions arose one after another and have never come to an end.

In this way in the first several years of the twentieth century the controversy was at white heat. Harnack and E. e. d. Lcy en's' experiment with dogs and rabbits showed that indican increased by intoxication with oxalic acid, and Moraczews $\mathrm{ki}^{105}$ observed in diabetes mellitus a parallel increase of indican and oxalic acid in urine and a parallel decrease of both by alkali injection; they were opposed to the theory of bacterial formation of indican. Blumenthal ${ }^{11}$ Rosenfeld and Lewin ${ }^{12}$ in a fasting experiment and phloridzin intoxication observed increased excretion of indican, thereby, however, without substantiating the existence of hemorrhage in the intestine and indol in the intestinal contents. On this ground they asserted that this increased indican was not caused by the action of bacteria.

Contrary to this assertion $\mathrm{S}\left(\mathrm{h} o l \mathrm{z}^{13)}\right.$ never noticed increased indican in the hunger state and in the case of intoxication with oxalic acid and phloridzin. Ellinger ${ }^{14}$ also advanced a theory that the increased indican 
in poisoning with oxalic acid was due to the hemorrhage in the intestinal canal, and ascribed the increased indican in the hunger state to the eating of stools and that no indol was found in stools due to the small quantity of materials examined.

Thus in 1911 Obermeyer and Popper ${ }^{15)}$ discovered the indican in blood, and in $1913 \mathrm{Jolles}^{16)}$ found a new method of indican proof, by which a very small amount of indican can be proved. After these investigations a new ficld was opened in the indican problem; that is, the blood indican in nephritis was examined and the relation between indicanuria, indicanemia and azotemia was studied. M. Rosen ber $\mathrm{g}^{17}$ observed in animal experiments increased indican in urine by oxalate poisoning, and increased indican in urine and blood by artificial nephritis with uranium, sublimate, chrom and cantharidin. He also observed at the same time increased urea in blood and concluded that the source of increased indican was perhaps outside of the digestive tube, rather that it was in the metabolic disorders of body protein.

\section{Matters Concerning the Experinents.}

If we look back upon the studies of our predecessors, we shall find that the account of different results of their experiments may be due partly to the lack of consideration of the diet and feces, partly to the different methods of indican proof, and partly to the lack of quantative determination of indican.

(a) It has been known since $\mathrm{J}$ affe $\mathrm{e}^{2}$ that the amount of indican varies with the quality of diet, and as a matter of fact, it is recognized generally that a flesh diet would increase indican. Therefore it would be useless to discuss the indican problem without considering the quality of diet.

(b) The disorder, in which most frequently we meet with indicanuria, is that of the digestive system ; therefore $I$ think it is also important and necessary always to keep the character of feces in mind.

(c) In the literature on indican, descriptions of the appetite are so rare that we can hardly find even one or two in it. But if we reflect that indican increases in the state of inanition, it must be also an important matter to take the state of appetite into consideration.

(d) The blame for the lack of a solution of this problem must be placed partly on the differences of indican proof and the lack of a simple quantative method. For example, with Jaffe's method if the amount of calcium chloride is too great, the produced indigo may decompose, and if the 
calcium chloride too little, the oxydation may remain incomplete. Therefore it may be difficult to criticize the amount of indican by this method. Obermeyer's method ${ }^{13}$ is superior in simplicity, but inferior in sensibility and almost no normal urines show indican reaction, so it is also inadequate for the quantative determination. 'Takeuch i's method ${ }^{19)}$ is more sensible than the former, yet even by this method certain urine proves itself to have no indican. Therefore we can not yet determine by it the exact quantity of indican. The method with $\mathrm{HCl}$ conc. and hydrogen peroxyde, which is used chiefly in France, ${ }^{20}$ may be called the most sensible (Y a n a mi), but according to my examination it is inferior to Jolles's method. Jolles's method is the most sensible of all indiean proof and is worthy to be recommended as most superior for the determination of indican. But it is to be regretted that to get the standard solution for this method is difficult in Japan.

(e) Stanford $d^{21}$ at first remarked that, if urine is allowed to stand long as it is, the amount of indican in it would diminish. G. HoppeSeyle $\mathrm{r}^{22}$ gave an explanation for this phenomen, saying that it was due to the formation of indigo blue and indigo red from indiean by the action of bacterium coli of certain stem. Recently Kötsehau ${ }^{239}$ observed two cases : in one case indican in urine decreased and in another case rather increased, when urines were allowed to stand long, and he has reported that it was caused by the activity of bacteria.

I placed confidence in their proposal, and therefore I washed the cages, the boxes for food and the receptacles for urine thoroughly with water every day and kept them as clean as possible and furthermore cxamined urines while they were fresh, as early as possible.

\section{Methods.}

(1) Determination of Indican in Urine and Blood.

(a) The determination of indican in urine.

In the beginning of this experiment I had not the standard solution for the colorimetric determination by Jolles's method, so I had to determine it by 'Takeuch i's ${ }^{10}$ method as follows:

20 c.c. of urine are measured into a test tube, 5 c.c. of $10 \%$ lead acetate solution are added, mixed and filtered. 10 c.e. of the filtrate are measured into a specially made tube, 1 c.c. of acetic acid, 3 c.c. of chloroform and 0.5 c.c. of Ta ke u ch i's reagent $(8.3 \mathrm{gm}$. $\mathrm{KCl}, 6.0 \mathrm{gm}$. $\mathrm{KBr}, 6.8 \mathrm{gm}$. J in 1000 c.c. water) are added. The mixture is shaken one or two times gently, 10 
c.c. of concentrated lyydrodhloric acid (sp. gr. 1.19) are added and shaken intensively one or two minutes. By this means the chloroform takes on a dark purple colour. (When the colour of chloroform is too intense, all the solution except the chloroform must be placed into another tube and once more extracted with chloroform in the same way as above). Then the solution except the chloroform is removed. Hereupon the chloroform is washed with water two times, and 5 c.c. of $2.5 \%$ sodium thiosulfate solution are added and well mixed. By this means the dark purple coloured chloroform changes its colour and takes the colour of indigo blue. A certain definite amount of this chloroform is pippeted into the colorimetric tube of Duboseq's colorimeter, diluted with glacial acetic acid to adequate concentration. Then the concentration of indican in the diluted chloroform extract is determined colorimetrically.

But by this method certain urine proves itself to have no indican, while by Jolles' method it proves evidently to have indican in it. In such a case it may be improper to estimate indican as zero. I then tried to make the standard solution for Jolles' method, and I was able to prepare it as follows :

Urine which contains a relatively large amount of indican is selected. The concentration of indican in it is determined beforehand according to Takeuchi's method above described. Then according to Jolles's method : ${ }^{29} 20$ c.c. of urine are measured into a test tube, 5 c.c. of $10 \%$ lead acetate solution are added, mixed and filtered. 10 c.c. of the filtrate (corresponding to 8 c.e. of urine) are measured into a test tube, 1 c.c. of $5 \%$ thymol alcoholic solution, 10 c.c. of Ober m ey er's reagent ( $5 \mathrm{gr}$. iron chloride per 1000 c.c. of conc. hydrochloric acid) are added, well mixed and allowed to stand two hours. After which a definite amount of chloroform is added, and the mixture is shaken intensively one or two minutes. By this means the chlorofurm takes on a violet colour. All the liquid except the chloroform is removed. The chloroform extract is diluted with glacial acetic acid four or five times. The concentration of indican in it can be recalculated from the concentration deternined by 'Takeuchi's method, and can be used as the standard solution.

But this solution is very volatile, so it is not fitted for the standard solution in Duboseq's colorimeter. Therefore I enclosed it in the wedge of Autenricth's colorimeter. This standard solution can be used for about one month after preparation. But, if the dilution with glacial acetic acid is small, fading may occur rapidly, so it is better to dilute it as much as possible. Further it is likely to fade by the action of light rays, so one 
must prevent it from fading by placing it in a lark place except for the time when it is used.

The determination of indican by Jolles's method is based upon the comparison of colour of the diluted chloroform extract, which is prepared in the same way as above to this standard solution with Autenrieth's colorimeter.

(b) The determination of indican in blood.

Indican in blood was determined according to the Stra uss's modification $^{25)}$ of Jolles's method : that is as follows:

4 c.e of serum are pippeted and poured into a large centrifuge tube, 4 c.c. of distilled water, 8 c.e. of $20 \%$ trichloracetic acid solution are added, well stirred and centrifuged. Superuatant fluid is poured into a test tube, 0,4 c.c. of $5 \%$ thymol alcoholic solution, 16 c.c. of Obermeyer's reagent are added and well mixed. The mixture is allowed to stand two hours. After which 1-2 c.c. of chloroform are added and shaken one or two minutes intensively. By this means the chloroform takes on a violet colour. Hereupon all the liquid except chloroform is poured of. The chloroform extract is diluted with glacial acetic acid. Then indican can be colorimetrically estimated with Autenrieth's colorimeter in the same way as in urine.

(2) Determination of the Total Amount of Blood and Blood-plasma in the Animal Body.

a. The determination of the total amount of blood in the animal body.

It may be improper to acknowledge the a mount of indican eliminated ouly in urine as the amount of produced indican in an organism. I estimated not only the indican in urine, but also in the total amount of blood in the animal body, and studied on one hand the changes of distribution of it in an organism at various conditions, and on the other hand the influences of different treatments on the indican formation. The indican in tissues may be neglected for the total amount of produced indican in the body, be(ause, according to Becher, ${ }^{33}$ the amount of indican in tissues is said to be very small even in the state of hyperindicanemia.

We have not at present a complete method for the estimation of the total amount of blood in the animal body. Plesch's method, ${ }^{96)}$ by which the total amount of blood in the animal body is calculated from proper 
formulae after estimation of hemoglobin contents before and after infusion of isotonic sodium chloride solution, is not only simple, but also it is said to be fairly accurate. It goes without saying that the ratio of the amount of blood to the body weight differs more or less in each case, but it may be admitted to supply the average ratio in a goolly number of cases to each ase provided that we have not an accurate method in fact.

The next figures slow the results obtained by 1r. Horiuchi, who estimated the total amount of blood in rabbits by Plesch's methorl in our Institute. Here let me express my thanks to Dr. Horiuchi for all the kindness he has

\begin{tabular}{|c|c|c|c|}
\hline Case No. & $\begin{array}{c}\text { Temperature } \\
\left({ }^{\circ} \mathrm{C} .\right)\end{array}$ & $\begin{array}{l}\text { Specific gravi- } \\
\text { ty of blood }\end{array}$ & $\begin{array}{c}\text { Ratio of blood } \\
\text { weight to } \\
\text { body weight } \\
(\%)\end{array}$ \\
\hline 1 & 18 & 1.055 & 8.48 \\
\hline 2 & 16 & 1.059 & 9.28 \\
\hline 8 & 20 & 1.055 & 8.12 \\
\hline 4 & 14 & 1.054 & 8.07 \\
\hline 5 & 11 & 1.059 & 8.31 \\
\hline 6 & 15 & 1.058 & 8.33 \\
\hline 7 & 13 & 1.061 & 7.90 \\
\hline 8 & 18 & 1.057 & 9.56 \\
\hline 9 & 15 & 1.057 & 8.0 \\
\hline 10 & 18 & 1.058 & 7.62 \\
\hline 11 & מll & 1.056 & 9.30 \\
\hline 12 & 11 & 1.057 & 8.28 \\
\hline $1: 3$ & 14 & 1.058 & 8.54 \\
\hline 14 & 15 & 1.057 & 7.98 \\
\hline 15 & I7 & I. 058 & 8.77 \\
\hline 16 & 15 & 1.057 & 7.03 \\
\hline 17 & 13 & 1.059 & 9.10 \\
\hline 18 & 15.5 & 1.052 & 8.72 \\
\hline 19 & 12 & 1.060 & 8.95 \\
\hline 20 & 17 & 1.059 & 9.04 \\
\hline 21 & 13 & 1.061 & 8.72 \\
\hline 22 & 16 & 1.057 & 8.20 \\
\hline 83 & 14 & 1.052 & 8.93 \\
\hline 24 & 10 & 1.058 & 8.70 \\
\hline 25 & 14 & 1.060 & 8.75 \\
\hline \multicolumn{2}{|c|}{ Average } & 1.057 & 8.50 \\
\hline
\end{tabular}
shown me.

From the above figures I calculated that on the average the ratio of body weight to weight of total amount of blood is as $100: 8.50$ and specific gravity of blood is 1.057 . Therefore the total amount of blood corresponds volumetrically 8.04 per cent of body weight, that is, $\frac{1}{12.3}$ of body weight. This average ratio was applied in all cases in my experiment for the calculation of total amount of blood of rabbit.

b. The determination of the total amount of blood-plasma in the animal body.

The ratio of the amount of blood-plasma to the total amount of blood 
differs in various conditions, so it must be determined in every case. It was determined by hematocrit procedure.

Hematorit procedure by $\mathrm{Hedin}^{27}$ is as follows : a definite amount of blood is mixed with a definite amount of Hedin's solution (sodium chloride $0.9 \mathrm{gr}$. , sodium oxalate $0.1 \mathrm{gr}$. in $100 \mathrm{c.c}$. aqua dest.) to prevent coagulation. 'The mixture is sucked up in the hematocrit capillary, and centrifuged (3000 revolutions a minute) for 10 minutes. By this means the corpuscle and the plasma are separated. Then the ratio of the amount of plasma to the amount of blood can easily be found by the scale on the capillary. Hence the total amount of plasma can be calculated from the total amount of blood in the animal body.

(3) Determination of the Amount of Hemoglobin.

The amount of hemoglobin was determined with A utcnrieth's colorimeter. It was for the purpose of examining the results obtained by the hematocrit procedure. It was found that the amount of hemoglobin ran always parallel with the results obtained by the hematocrit procedure.

\section{Experimextal.}

1. The Influence of Diet on the Indican Formation.

Formerly Gautier reported that rabbits nourished with eabbages did not eliminate indican. Recently Distaso stated that guinen-pigs nourished with cabbages and hay did not excrete indican, and in feces bac. coli was absent, but if the guinea-pigs were nourished with oats, bran and cabbages, both indican and bac. coli were present. On this account he concluded that the presence of indican necessitates the artivity of bac. coli in the digestive tube.

At the ontset of this experiment I intended to certify Distaso's proposition. 11 guinea-pigs wore used for experiment, atl of them nourished exclusively with cabbages. During cabbage diet the indican in urine and the bac. coli in feces were investigated. The indican proof was made by Jolles's method. The results are mentioned in Table $\mathbf{I}$.

As shown in Table I the result of this experiment was contrary to the result of Distaso. Guinea-pigs were nourished exclusively with cabbages from nine to sixty days, and during which time indican in urine was tested every day by Jolles's methor, and it was never absent even once. In the 
'YABLE I.

\begin{tabular}{|c|c|c|c|c|}
\hline $\begin{array}{c}\text { Guine:-pig } \\
\text { No. }\end{array}$ & Date & Duration & Indican & B. coli \\
\hline $\begin{array}{r}1 \\
2 \\
3 \\
4 \\
5 \\
6 \\
7 \\
8 \\
9 \\
10 \\
11\end{array}$ & $\begin{array}{l}\text { Sept. } 22 \text {-Oct. } 11926 \\
\text { Sept. } 22 \text {-Oct. } 1 \\
\text { Sept. } 22 \text {-Sept. } 30 \\
\text { Oct. } 2 \text {-Oct. } 14 \\
\text { Oct. } 2 \text {-Oct. } 13 \\
\text { Oct. 2-Nov. } 8 \\
\text { Oct. } 17 \text {-Dec. } 15 \\
\text { Oct. } 17 \text {-Nov. } 11 \\
\text { Nov. } 12 \text {-Dec. } 21 \\
\text { Nov. } 29 \text {-Dec. } 24 \\
\text { Dec. } 24 \text {-Jan. } 201927\end{array}$ & $\begin{array}{r}10 \\
10 \\
9 \\
13 \\
12 \\
38 \\
60 \\
26 \\
40 \\
29 \\
23\end{array}$ & $\begin{array}{c}\text { present } \\
\text { " } \\
" \\
" \\
" \\
" \\
" \\
" \\
" \\
"\end{array}$ & $\begin{array}{c}\text { Oct. } 22 \text { present } \\
, " \\
\text { Dec. } 16 \text { present } \\
, "\end{array}$ \\
\hline
\end{tabular}

course of this experiment it was noticed that if the diet was somewhat too little, it occurred that the excretion of indican somewhat increased. Therefore in the cases above mentioned the guinea-pigs were always carefully nourished with plenty of cabbages.

Bacterium coli in feces were examined in two other guinea-pigs (besides these four (ases in the table) nourished exclusively with lees of bean curds and in one human feces. The research for bac. coli was as follows : bac. coli were isolated from the feces by means of Endo's nutrient medium and inspected on one hand microscopically and on the other hand determined by cultural properties with neutral red, agar, lactose-agar, milk and pepton water. In case No. 7 and No. 10 no colony developed on Endo's nutrient medium ; namely bac. coli were absent. In other cases there were found bacilli, which must be admitted as bac. coli on the ground that they were $\mathrm{Gram}$ negative bacilli and their cultural properties were equal to those of bac. coli.

I learned in this experiment that the numbers of bac. coli in the feces of guinea-pigs, as a rule, were very small without difference, whether they were nourished with cabbages or lees of bean curds, in comparison with those in the feces of human subject; that is to say, while in the human being scores of colonies were formed on the nutrient medium, when it was smeared over with diluted feces with physiological salt solution, in guineapigs sometimes no colony developed on the nutrient medium, when it was smeared over with diluted feces, and only a few colonies could just be seen, when it was smeared over with the feces itself. Hence the absence of bac. (oli in some of my cases may not be attributed to the cabbage diet, and it may well be said that the absence of bac. coli in Distaso's experiment may have resulted from this circumstance. 
As to indican, though the indican reaction was always positive in each case as shown above, the quantity was so small that it was scarcely discovered with Jolles's method, and not at all with Takeuchi's. Therefore it seems indisputable that Distaso in his experiment did nut see indican by his indican test with hydrochloric acid and hydrogen peroxyde solution.

2. The Influence of Inanition on the Indican Formation.

Guinea-pig No. 8 was nourished exclusively with cabbages. The amount of urine was measured every day. The indican in urine was tested by Jolles's and 'Takeuchi's methods.

\section{Tabie II.}

Guinea-pig No. 8.

\begin{tabular}{|c|c|c|c|c|c|c|c|}
\hline \multirow{2}{*}{$\begin{array}{l}\text { Date } \\
1926\end{array}$} & \multirow{2}{*}{$\begin{array}{l}\text { Body- } \\
\text { weight } \\
\text { gm. }\end{array}$} & \multirow{2}{*}{ Diet } & \multirow{2}{*}{ Treatment } & \multirow{2}{*}{$\begin{array}{c}\text { Crine } \\
\mathrm{ce} .\end{array}$} & \multicolumn{2}{|c|}{ Indican } & \multirow{2}{*}{ Rematri: } \\
\hline & & & & & $J$ & $\mathrm{~T}$ & \\
\hline $\begin{array}{cc}6 . & \text { XII } \\
7 . & " \\
8 . & " \\
9 . & " \\
10 . & " \\
11 . & " \\
12 . & " \\
13 . & " \\
14 . & "\end{array}$ & $\begin{array}{l}380 \\
383 \\
390 \\
396 \\
382 \\
404 \\
392 \\
380 \\
356\end{array}$ & $\begin{array}{c}\text { cabbuage } \\
", \\
"\end{array}$ & f.st $\begin{array}{r}10: 30 \text { a.mi. } \\
-4 \cdot 30 \text { p.m. }\end{array}$ & $\begin{array}{c}85 \\
115 \\
115 \\
130 \\
15 \text { inuring fitst } \\
\text { (5) : f fur fant } \\
80 \\
40 \\
20 \\
35\end{array}$ & $\begin{array}{c}+ \\
+ \\
+ \\
+ \\
++ \\
+ \\
+ \\
+ \\
++ \\
+\end{array}$ & $\begin{array}{l}- \\
- \\
- \\
+ \\
- \\
- \\
+ \\
+\end{array}$ & 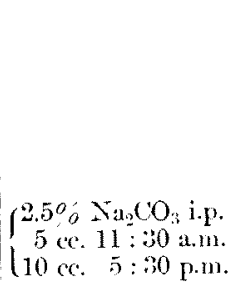 \\
\hline
\end{tabular}

$\mathrm{J}=\mathrm{J}$ olles's method. $\mathrm{T}=\mathrm{T}$ ake uc h i's method.

As shown in Table II when the guinea-pig was nourished with plenty of food, the indican reaction of urine was negative by Takeuchi's method, and weakly positive by Jolles's. But on Dec. 10th when it was fasted six hours, the indican reaction became weakly positive by 'Takeuchi's method and moderately so by Jolles's. Again on Dec. 13th it was fasted for 24 hours, and the indican reaction of urine excreted during that time was positive by Takeuchi's method and strongly positive by Jolles's method. In view of this fact it is evident that guinea-piess readily excrete increased indican after several hours' fast.

Moraczewski ${ }^{10}$ informed us that the amount of indican in urine was controlled by the reaction of the urine, and if the reaction was made alkaline by injection of soda solution into the organism, the amount of in- 
dican in urine decreased. But the result of my experiment differed from that of Moraczewski, namely, as shown in Table II, though the urine excreted in the second period of fasting was made alkaline by injection of sodium carbonate solution, yet the indican in urine by no means decreased, and even increased.

Guinea-pig No. 10.

TABi,e III.

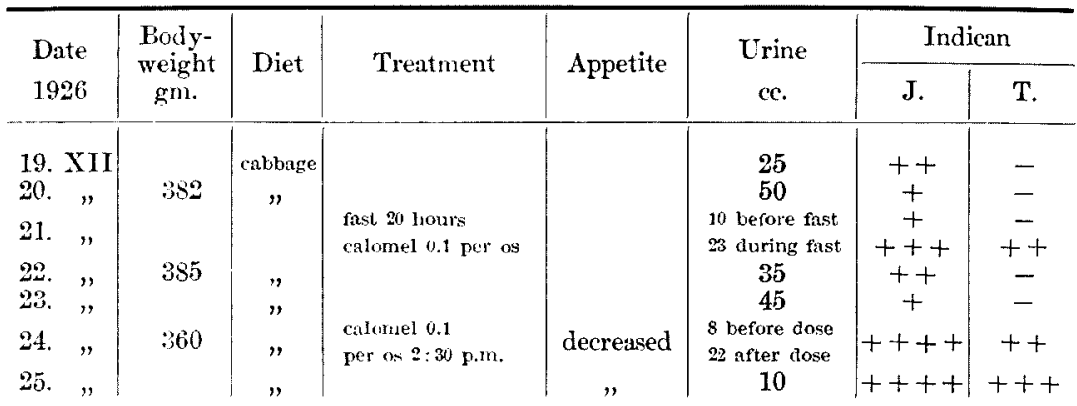

It may be considered that the increase of indican in fasting might have resulted from the resorption of a large amount of indol, which was produced in the intestine by stagnation of feces. Therefore in the case of Table III the guinea-pig was fasted and at the same time the intestinal contents were discharged by calomel, and then the urine excreted during which time it was examined for indican. I saw that there was not any change in the amount of indican on this account, namely, indican in urine by no means diminished by rapid discharge of intestinal contents. This result is contrary, on the other hand, to Baumann's opinion, ${ }^{7}$ wbich maintained that indican in urine diminished by disinfection of the intestine with calomel.

Next rabbits were used for experiment for the convenience of obtaining blood. They were nourished with lees of bean curds; the body weight, and the amount of diet and urine were measured every day; the state of appetite and the character of feces were always carefully noticed. As regard to indican, the total amount of it in blood and urine was determined. The details are mentioned in Tables IV, V, VI, VII.

As shown in the tables, in these experiments not only the amount of indican in urine, but also the total amount of indican in blood of the animal body were estimated. Therefore the total amount of indican formed in the organism in 24 hours could be estimated in figures. We see the total 
Experimental Studies on Indican Formation. I.

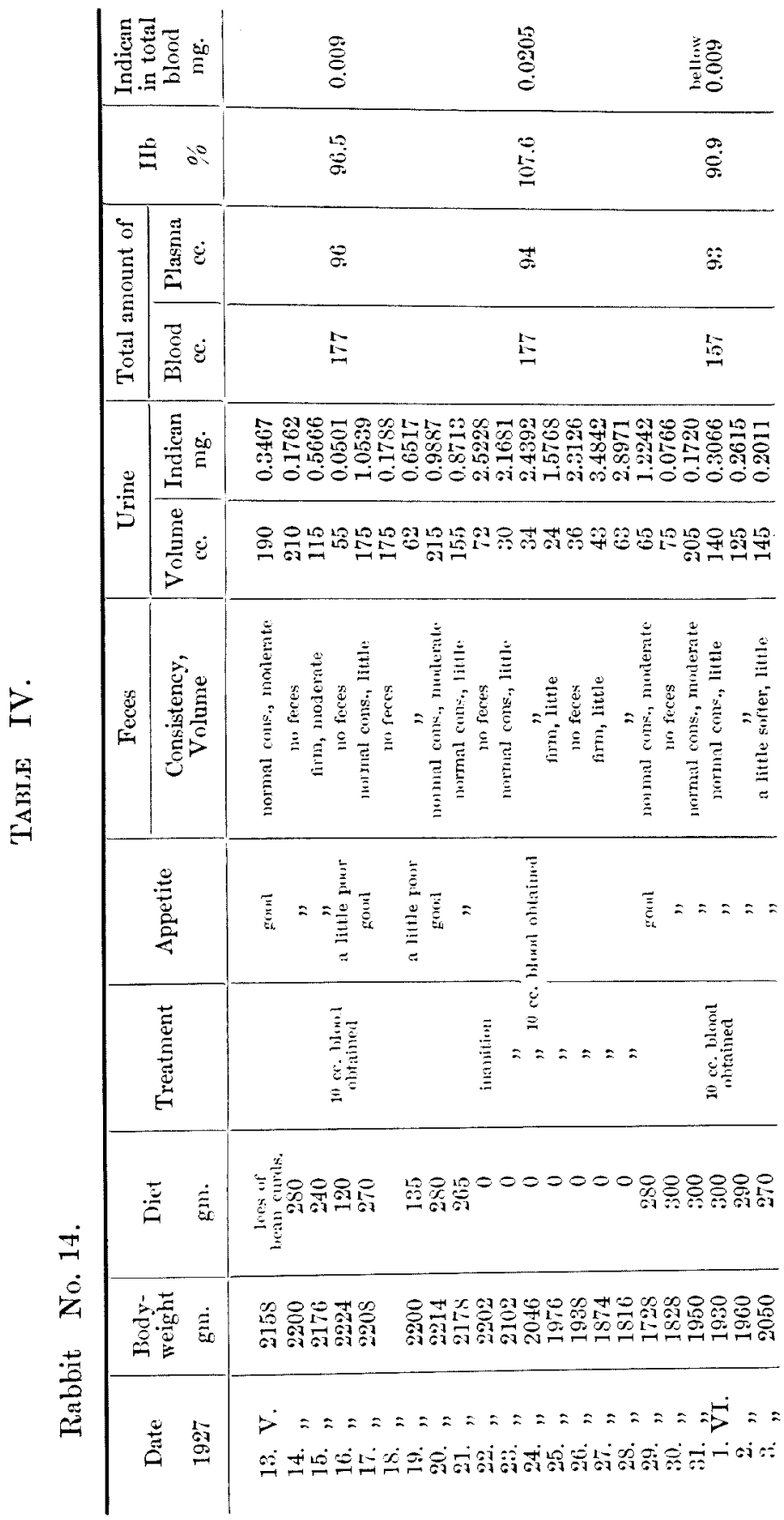




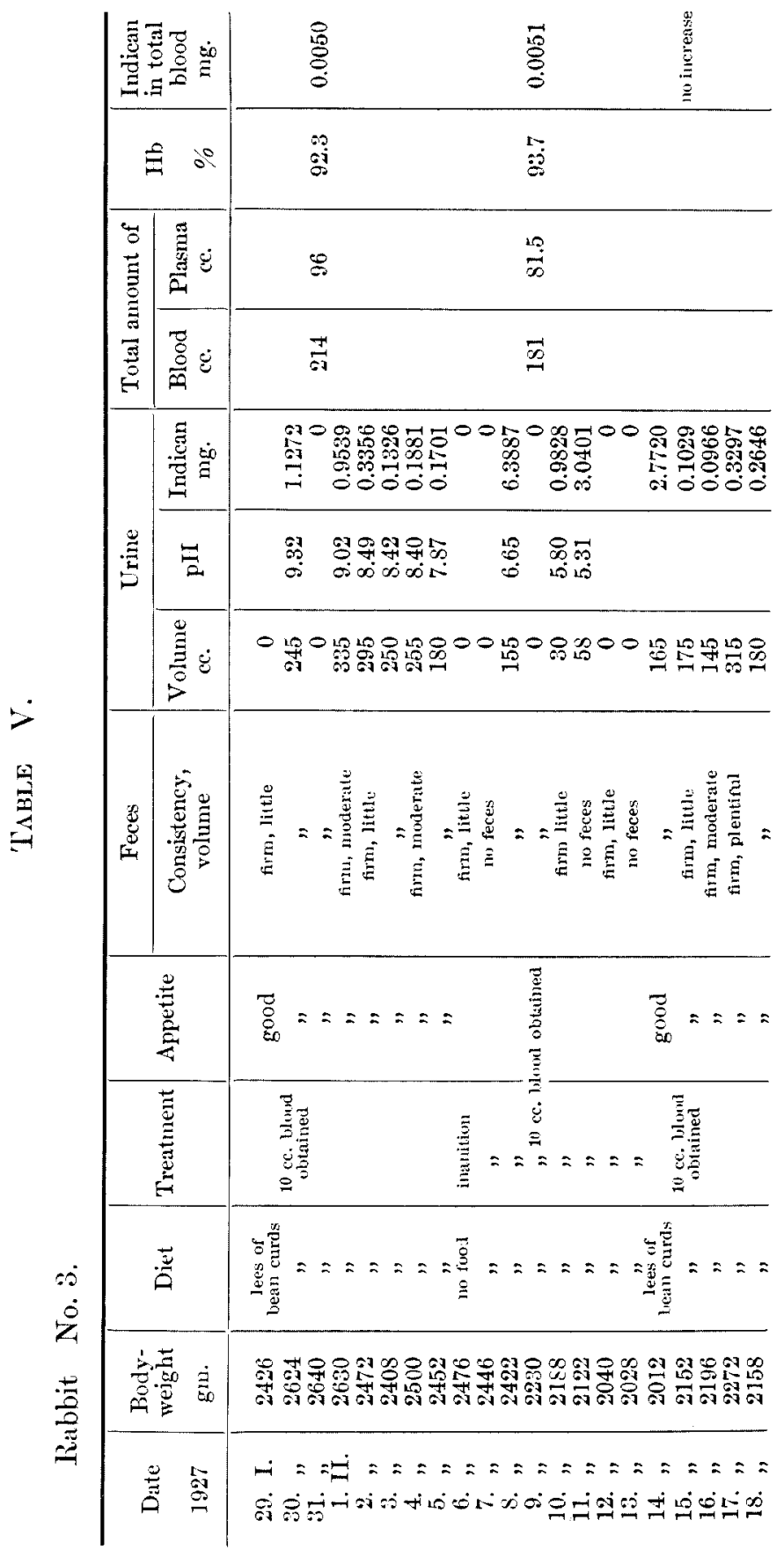


Experimental Studies on Indiean Formation. I.

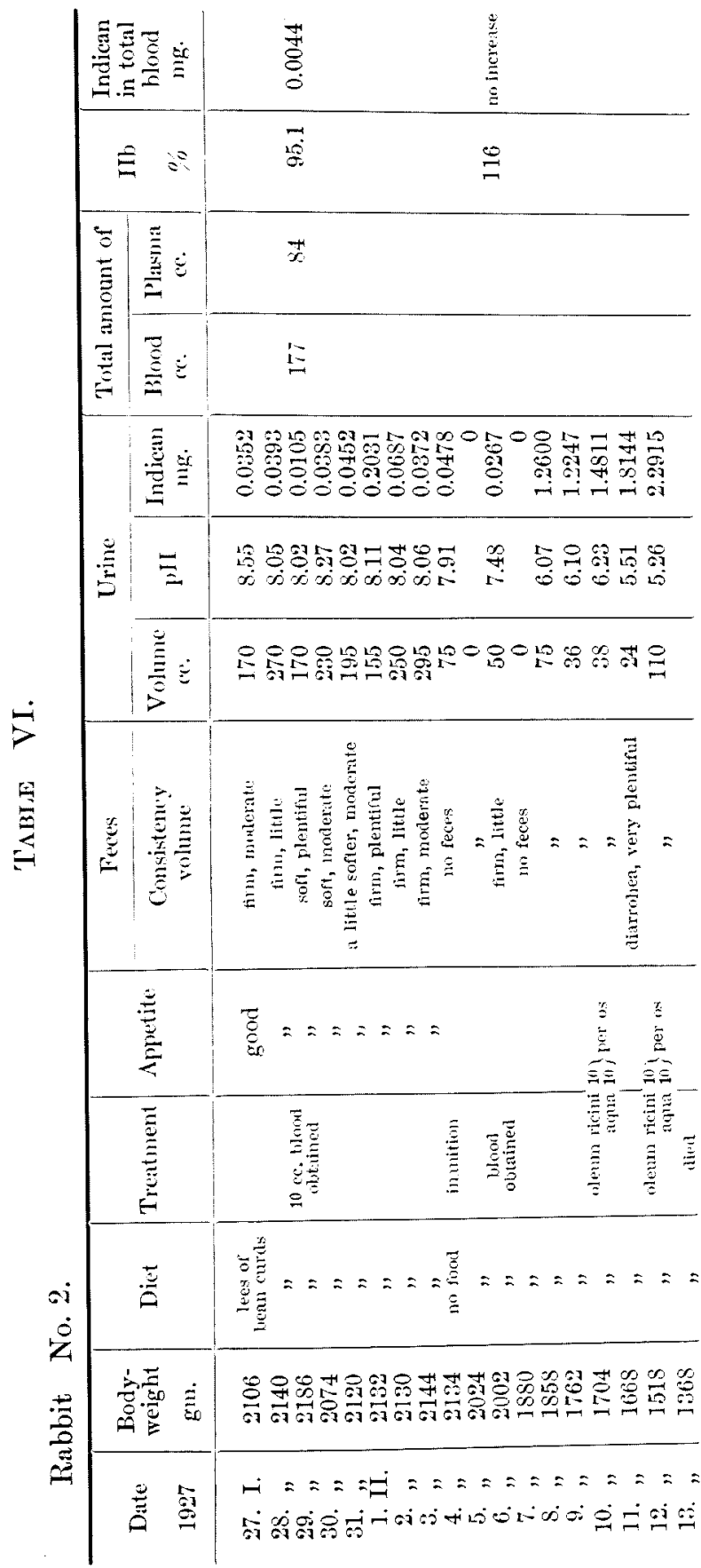

amount of indican increasc's during the period of fasting in cvery case without exception. Now if we look upon the distribution of the indican increased thereby, we will find that the increase of it is for the most part in the urine, and not in the blool. Generally indican in blocd stays normal except in the case of table IV, in which it increases a little.

According to the researches of our predecessors, ${ }^{3}$ if fasting continued longer, the indican in urine decreased. But according to my experiment, on the contrary, the indican in urine never decreased, rather it increased rapidly 
Experimental Studies on Indican Formation. I.

on the first day, and this state continued on invariably during seven to ten days' fasting in every case. Therefore it must be conceived as a fact that indican increases in inanition, yet it is a question, whether the increased indican is due to the stagnation of intestinal contents or not. Therefore, in the case shown in table VI the intestinal contents were discharged with oleum ricini on the seventh day of fasting. Neverthless indican still similarly increased. 'Therefore it may well be said that the increase of indican was due merely to the inanition, and the stagnation of intestinal contents had no part in it. If that be the casc,

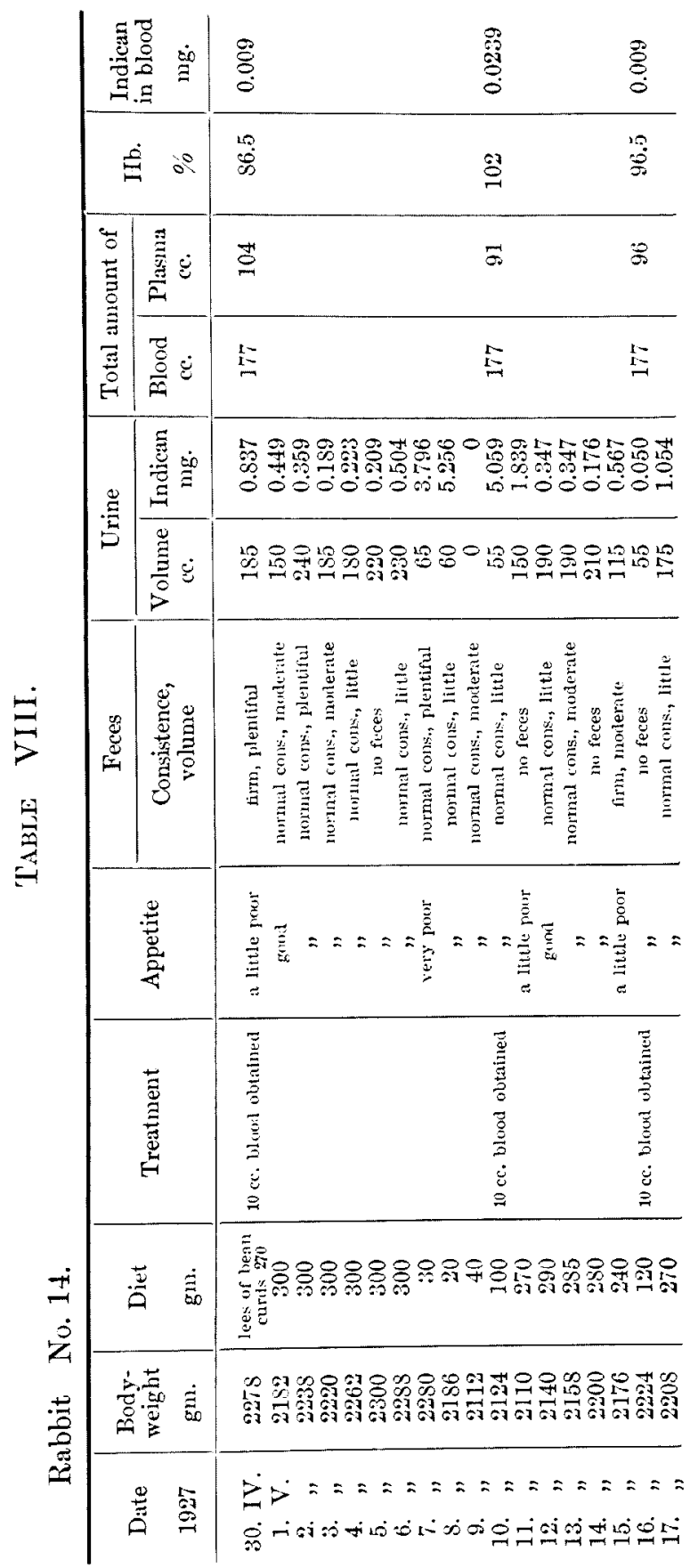


Rabbit No. 5.

TABIE IX.

\begin{tabular}{|c|c|c|c|c|c|c|}
\hline \multirow{2}{*}{$\begin{array}{l}\text { Date } \\
1927\end{array}$} & \multirow{2}{*}{$\begin{array}{c}\text { Body- } \\
\text { weight } \\
\text { gm. }\end{array}$} & \multirow{2}{*}{$\begin{array}{l}\text { Diet } \\
\text { gm. }\end{array}$} & \multirow{2}{*}{ Appetite } & Feces & \multicolumn{2}{|c|}{ Urine } \\
\hline & & & & $\begin{array}{l}\text { Consistence, } \\
\text { volume }\end{array}$ & $\begin{array}{c}\text { Volume } \\
\text { cc. }\end{array}$ & $\begin{array}{l}\text { Indican } \\
\text { mg. }\end{array}$ \\
\hline 21. II. & 1320 & $\begin{array}{l}\text { lees of hern } \\
\text { curds } 270\end{array}$ & poor & diarrhea, plestiful & 26 & 0.2168 \\
\hline $22 .$, & 1230 & $n$ & $"$ & & 30 & 2.5536 \\
\hline $23 .$, & 1164 & ", & , & diarrhea, little & 58 & 5.5540 \\
\hline 24 & 1114 & ", & $"$ & a little softer, moderate & 55 & 3.0083 \\
\hline $25 . "$ & 1130 & 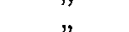 & a little improver & normal cons., little & 100 & 1.1400 \\
\hline 26. & 1168 & $"$ & good & no feces & 145 & 0.6061 \\
\hline 27 & 1212 & ", & " & , & 155 & 0.5890 \\
\hline 28. & 1220 & $"$ & " & a little softer, plent. & 160 & 1.3619 \\
\hline 1. III. & 274 & 11 & a little poor & no feces & 140 & 1.7024 \\
\hline 2 & $125 \mathrm{~s}$ & 160 & , & $"$ & 140 & 1.3896 \\
\hline 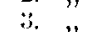 & 246 & 150 & $"$ & " & 110 & 1.3376 \\
\hline 4. , , & 1272 & 110 & 3 & $n$ & 95 & 1.5306 \\
\hline 5. & 1280 & 80 & poir & $"$ & 115 & 1.4858 \\
\hline 6. & 1276 & 210 & a lititle improved & firm, plentiful & 160 & 1.7280 \\
\hline 7. , & 1288 & 280 & & normal cons., moderate & 120 & 1.1232 \\
\hline s. & 1282 & 200 & $"$ & softer, molerate & 100 & 1.7280 \\
\hline $9 . "$ & 1278 & 200 & $"$ & normal cons., moderate & 90 & 1.3996 \\
\hline 10. & 1290 & 170 & a litule por & & 115 & 1.5870 \\
\hline 11. & 1272 & 50 & poor & normal cons., plentiful & 80 & 1.5640 \\
\hline 12. " & 1292 & 200 & a little improved & softer, moderate & 75 & 0.6106 \\
\hline 13. , & 1306 & 250 & yood & normal cons., plentiful & $\begin{array}{l}\text { casted } \\
\text { away }\end{array}$ & \\
\hline $14 .$, & 3.74 & 250 & $n$ & normal cons., little & 175 & 0.5232 \\
\hline
\end{tabular}

Rabbit No. 7.

TABle $\boldsymbol{X}$.

\begin{tabular}{|c|c|c|c|c|c|c|}
\hline \multirow[b]{2}{*}{$\begin{array}{l}\text { Date } \\
192 \%\end{array}$} & \multirow{2}{*}{$\begin{array}{l}\text { Body- } \\
\text { weight } \\
\text { gni. }\end{array}$} & \multirow[b]{2}{*}{$\begin{array}{l}\text { Diet } \\
\text { gut. }\end{array}$} & \multirow[b]{2}{*}{ Appetite } & \multirow{2}{*}{$\frac{\text { Feces }}{\begin{array}{c}\text { Consistence, } \\
\text { volume }\end{array}}$} & \multicolumn{2}{|c|}{ Urine } \\
\hline & & & & & $\begin{array}{c}\text { Volume } \\
\text { ce. }\end{array}$ & $\begin{array}{c}\text { Indican } \\
\text { mg. }\end{array}$ \\
\hline 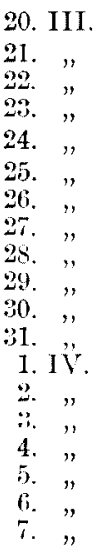 & $\begin{array}{l}1964 \\
1928 \\
1948 \\
1942 \\
1966 \\
1960 \\
1990 \\
1944 \\
1928 \\
1740 \\
1658 \\
1572 \\
1494 \\
1462 \\
1418 \\
1384 \\
1274 \\
1200 \\
1176\end{array}$ & $\begin{array}{c}\text { lees of bean } \\
\text { cuxds } 250 \\
250 \\
250 \\
250 \\
250 \\
250 \\
120 \\
10 \\
10 \\
20 \\
0 \\
0 \\
0 \\
30 \\
0 \\
0 \\
0 \\
0\end{array}$ & $\begin{array}{c}\text { good } \\
", \\
" \\
" \\
" \\
\text { pour } \\
\text { very poor } \\
", \\
\text { totally lost } \\
, \\
" \\
\text { very poor } \\
\text { totally lost } \\
", \\
" \\
\text { died }\end{array}$ & $\begin{array}{c}\text { normal cons., plentiful } \\
\text { firm, plentiful } \\
" \\
" \\
" \\
\text { diarruea, moderate } \\
\text { " } \\
\text { diarrhea, little } \\
\text { diarrhea, moderate } \\
\text { diarrhea, Jittle } \\
\text { no feces } \\
\text { " } \\
\text { " } \\
\text { diarrhea, plentiful } \\
\text { diarrhea, moderate } \\
\text { " }\end{array}$ & $\begin{array}{r}140 \\
120 \\
180 \\
110 \\
\text { cisted } \\
\text { aw:ay } \\
170 \\
55 \\
35 \\
55 \\
55 \\
100 \\
17 \\
25 \\
45 \\
28 \\
80 \\
52 \\
0\end{array}$ & $\begin{array}{r}1.5640 \\
1.1385 \\
1.4490 \\
2.6109 \\
4.3929 \\
6.8608 \\
2.6982 \\
4.1760 \\
8.9396 \\
3.5266 \\
10.7520 \\
7.2883\end{array}$ \\
\hline
\end{tabular}


what possession does indican hold in partial inanition? The next experiment was undertaken to determine this.

The three cases above mentioned in tables VIII, IX, $X$ are cases of partial inanition, although the degree of inanition differed. In each case the amount of urine, the body weight and the amount of diet were measured every day, and the relation of the a mount of indican to appetite or to body weight was carefully noticed. Then we see, as the tables show, a certain definite relation between them; that is to say, the more the appetite decreases, the more the amount of indican increases. Namely, if the body weight decreases, the amount of indican increases, and as a rule, the increase of indican runs parallel to the decrease of body weight.

It is said that in disorders of the digestive tube, especially in diarrhea we meet most frequently with indicanuria. Therefore many investigators have hitherto endea voured to find the source of indicanuria in diarrhea and commented that indican is derivative from indol formed in the intestine by bacteria and were satisfied with the theory that indican is formed by bacteria in the intestine.

But according to the result of this experiment the amount of indican has no relation to the character of feces, diarrhea or constipation. It depends solely on the state of appetite, namely, to the decrease of body weight.

3. The Influence of Parenterally Introduced Liver or Kidney Cells on the Indican Formation.

According to Miyagawa, ${ }^{30}$ if the constituent of organ cells is parenterally introduced into a living organism, it effects electively the homologous organ as a stimulus, and if the stimulation is too strong, the necrosis of that organ would take place. His theory is based on his own experiment.

I tried this experiment with the view to determine, if the necrosis of living colls is caused by injection of a large amount of dead cells, what influence it has on the indican formation.

Guinea-pigs were used for the experiment, and cells of liver and kidney were obtained from rabbits. The emulsion of those cells was prepared according to Sakurabayashi's method. ${ }^{31}$ In brief it is made as follows: through aorta descendens a large amount of physiological salt solution is infused under pressure, so that the tissues and organs will be thoroughly free from blood; then the liver and the kidney are taken out, crushed by the finger tip, wrapped in some sheets of gauze, pressed out into a centrifuge tube, and physiological salt solution is added, well stirred and centrifuged. 


\section{Table XI.}

Guinea-pig No. 6.

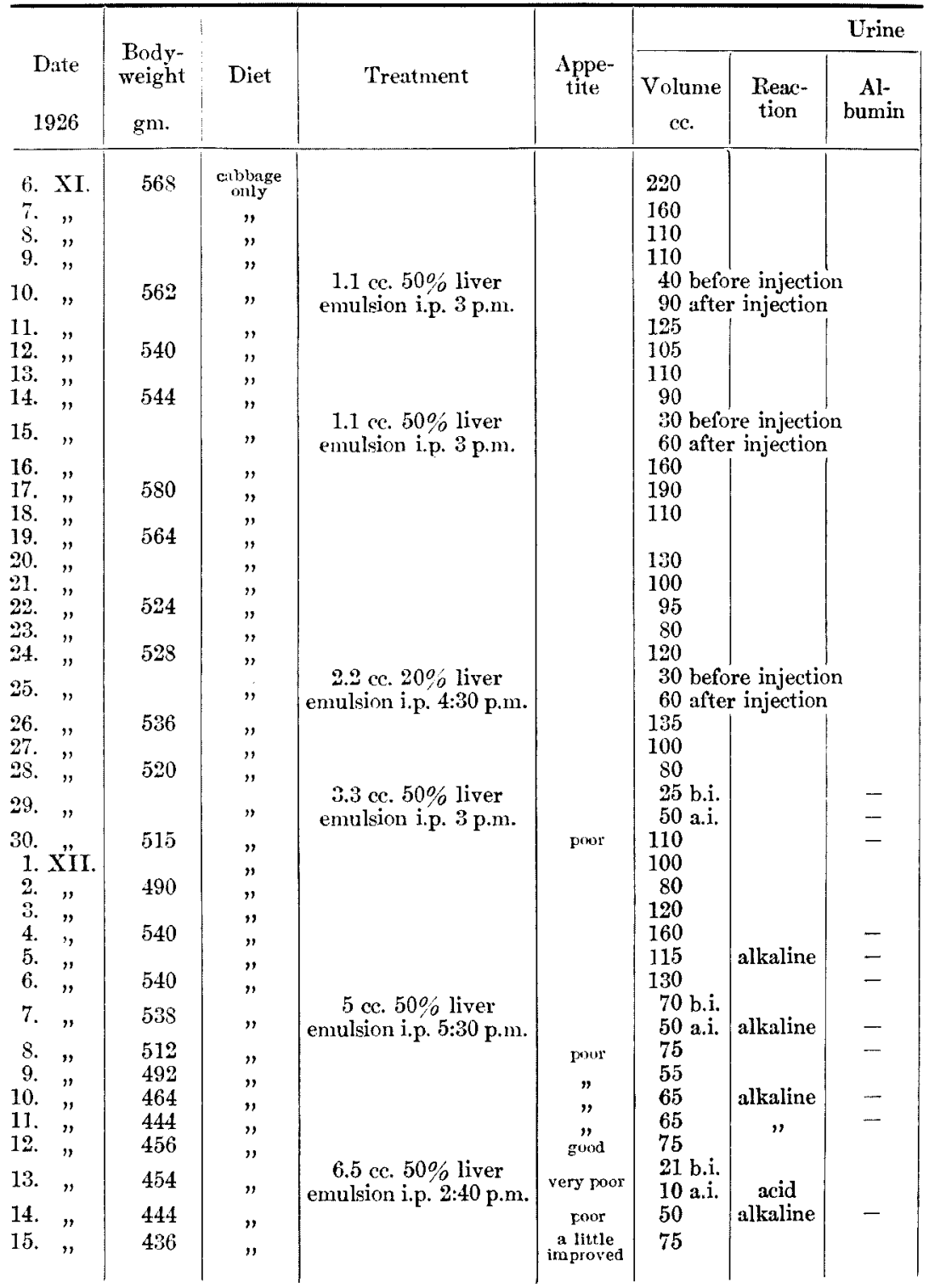


The supernatant fluid is removed. This procedure is repeated two or three times more so that the supernatant fluid will become clear. Then once more physiological salt solution is added to the precipitate so as to obtain $50 \mathrm{~g} / \mathrm{dl}$. cmulsion.

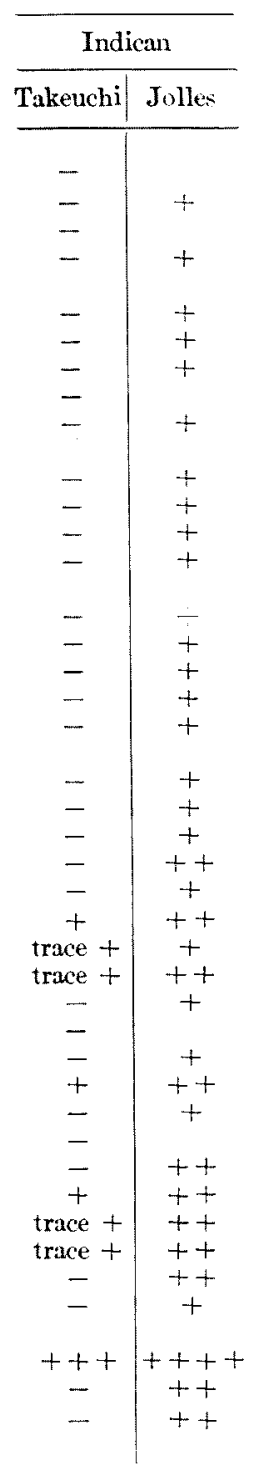

(a) Experiment with liver cells.

The emulsion of liver cells prepared as above was injected into the peritoneal cavity of a guineapig in a dose of 2-3 c.e. per kilogram of body weight. The results are shown in table XI.

I have experienced that when the emulsion over 6 c.e. per kilogram was introduced there was always an increase of indican. But I must point out here that the increase of indican was alrays attended by lose of appetite.

(b) Experiment with kidney cells.

The emulsion of kidney cells prepared as above was administered into the peritoneal cavity of a guinca-pig at the rate of 4 c.c. per kilogram of body weight. As shown in table XII it resulted more or less in the increase of indican in every case. In this experiment remarkable loss of appetite was not noticed.

By the above described experiments it became clear that if a large amount of liver or kidney cells is introduced parenterally into living organism, it eauses an increase of indican in urine. But it is not easily determined, whether the increase of indican was due to the necrosis of the organ cells, or due to another cause. 'Though in the experiment with hidney cells remarkable loss of appetite was not noticed, it is hard to say here that there was not truly any change of appetite, because the mass of caffage caten was not estimated in the present investigations. Then it is very natural that the guinea-pig showed increased excretion of indican in the state of lose of 


\section{Guinea-pig No. 10.}

\section{TABIL XII.}

\begin{tabular}{|c|c|c|c|c|c|c|c|c|}
\hline \multirow{3}{*}{$\begin{array}{l}\text { Date } \\
1926\end{array}$} & \multirow{3}{*}{$\begin{array}{l}\text { Body- } \\
\text { weight } \\
\text { gm. }\end{array}$} & \multirow{3}{*}{ Diet } & \multirow{3}{*}{ Treatment } & \multirow{3}{*}{ Appe- } & \multicolumn{4}{|c|}{ Urine } \\
\hline & & & & & \multirow{2}{*}{$\begin{array}{c}\text { Volume } \\
\text { cc. }\end{array}$} & \multirow{2}{*}{$\begin{array}{l}\text { Al- } \\
\text { bumin }\end{array}$} & \multicolumn{2}{|c|}{ Indican } \\
\hline & & & & & & & $\begin{array}{l}\text { Take- } \\
\text { uchi }\end{array}$ & Jolles \\
\hline 5. XII. & & $\begin{array}{l}\text { cabbrge } \\
\text { only }\end{array}$ & & & 50 & & - & + \\
\hline 6. , & 426 & $"$ & & good & 90 & & - & + \\
\hline 7. & 428 & $"$ & 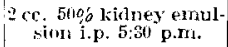 & $"$ & $\begin{array}{l}35 \text { before inj. } \\
55 \text { after inj. }\end{array}$ & - & - & ++ \\
\hline $\begin{array}{rl}8 . & , \\
1 \% & " \\
10 . & ", \\
11 . & ",\end{array}$ & $\begin{array}{l}412 \\
402 \\
406 \\
400\end{array}$ & $\begin{array}{l}" \\
" \\
"\end{array}$ & & good & $\begin{array}{r}95 \\
105 \\
115 \\
85\end{array}$ & & - & + \\
\hline 12. " & 402 & $"$ & $\begin{array}{l}2 \text { ce. } 50 \% \text { kirney emnl- } \\
\text { sion i.p. } 0.80 \text { n.m. }\end{array}$ & good & $\begin{array}{l}4 \mathrm{~b} . \text { inj. } \\
45 \text { a. inj. }\end{array}$ & - & - & ++ \\
\hline $\begin{array}{l}13 . ", \\
14 . ",\end{array}$ & $\begin{array}{l}374 \\
878\end{array}$ & ", & & & $\begin{array}{l}40 \\
55\end{array}$ & & - & + \\
\hline 15. , & 898 & ", & & & 115 & - & - & + \\
\hline
\end{tabular}

appetite, seeing that it eliminated a large amount of indican under only a few hours' fast. And so there may be no need to consider the direct action of the introduced cells for the explanation of the increased indican in these experiments. Indeed, if we observe the results of the experiments without considering the state of appetite of the animals, we may think of the increase of indican as the direct influence of the introduced cells, but if we take the state of appetite into consideration, it may be difficult to conclude it as such on the spot.

4. What Changes in the Amount of Indican Pake Place in Nephritis?

Since the discovery of Jolles's method a very small quantity of indiran has been proved. Nowadays it is generally known that even normal blood contains indican in it, and it is recognized that the indican in blood increases in nephritis. But the relation of indican in blood to the indiran in urine or the urea in blood has been still unsettled.

Rosenberg ${ }^{17)}$ observed in his experiment with rabbits that in the early stadium of nephritis the indican in blood and urine increased at the same time; in the late stadium, however, though the indican in blood increasel, yct indican in urine decreased. Thereupon he concluded that the increase of indican in blood in the early stadium is due to the increase of indican formation, while in the late stadium it is due to the retention of 
indican in blood in addition to the increase of indican formation. Further he observed that the increase of indican and urea in blood ran always parallel ; furthermore he observed that iudican in urine was increased by repeated iujection of urea, and he concluded that the indican formation was caused secondarily by the increase of urea in blood.

On the contrary, $\mathrm{H}$ a a ${ }^{32}$ insisted that the increase of indican in blood in nephritis was resulted by the retention of indican prior to other residual nitrogen compounds, and the increase of indican in bloxd was not accompanied with increased urea in blood.

Still a question remained, whether the increase of indican in blood may be due only to retention, or besides this to the inerease of indican formation. I thought it would become a key to the mechanism of indican formation, if this problem was made clear. Then the next experiment was undertaken with the purpose to settle this problem.

\section{a. In uran nephritis.}

Rabbits were used for experiment, nourished with only lees of bean curds. Nephritis was caused artificially by subcutaneous injection of 0.5 c.e. of $1 \%$ uranium acetate solution. The total amount of indican in blood and urine before and after the injection was estimated. As I had experienced in the former experiment that there existed an intimate relation between the amount of indican and the state of appetite, I never neglected to measure the diet and body weight every day. The result is recorded in tables XIII, XIV, XV, XVI.

As shown in table XIII, after injection of uran during eight days the rabbit showed loss of appetite, gradual decrease of body weight, sometimes diarrhea ; the amount of urine decreased, urine contained albumin, that is, the rabbit was taken ill with nephritis. In this case the excretion of urine continued fairly well ; the amount of hemoglobin and the proportion of the amount of plasma to the amount of blood remained normal; that is, an hydremic state was not present.

As to indican, in the carly stadium the amount of indican decreased in urine and increased in blood ; on the contrary, in the late stadium, when albumin in urine disappeared, and the appetite somewhat recovered and the body weight began to increase, it increased in urine and decreased in blood nearly to normal. Then from what did the increase of indican in blood in the early stadium of the nephritis result? As evidently shown in the table, the answer may be that it was due to the retention of indican 
Rabbit No. 3.

TABIE

\begin{tabular}{|c|c|c|c|c|c|}
\hline \multirow{2}{*}{$\begin{array}{l}\text { Date } \\
1927\end{array}$} & \multirow{2}{*}{$\begin{array}{c}\text { Body- } \\
\text { weight } \\
\mathrm{gm} .\end{array}$} & \multirow{2}{*}{$\begin{array}{l}\text { Diet } \\
\text { gns. }\end{array}$} & \multirow[b]{2}{*}{ Treatment } & \multirow{2}{*}{ Appetite } & Feces \\
\hline & & & & & $\begin{array}{c}\text { Consistence, } \\
\text { volume }\end{array}$ \\
\hline $\begin{aligned} 6 . & \text { III. } \\
7 . & , \\
8 . & " \\
9 . & ", \\
10 . & ", \\
11 . & " \\
12 . & " \\
13 . & ,\end{aligned}$ & $\begin{array}{l}2430 \\
2532 \\
2452 \\
2486 \\
2434 \\
2406 \\
2430 \\
2430\end{array}$ & $\begin{array}{c}\text { Lees of } \\
\text { bean } \\
\text { curds } 350 \\
130 \\
350 \\
350 \\
350 \\
220 \\
300 \\
250\end{array}$ & $\begin{array}{l}0.5 \text { c.c. } 10 \% \text { urmimm } \\
\text { acetate s. c. }\end{array}$ & $\begin{array}{l}\text { poor } \\
\text { good } \\
", \\
\text { a little poor } \\
\text { good } \\
\text { " }\end{array}$ & $\begin{array}{c}\text { firm, moderate } \\
\text { normal cons., plentiful } \\
\text { " } \\
\text { firm, moderate } \\
\text { firm, little } \\
\text { normal cons., moderate } \\
\text { ", }\end{array}$ \\
\hline 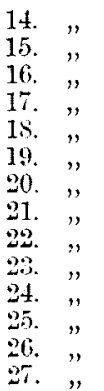 & $\begin{array}{l}2404 \\
2368 \\
2368 \\
2816 \\
2242 \\
2266 \\
2024 \\
2030 \\
1918 \\
2038 \\
2172 \\
2090 \\
2110 \\
2244\end{array}$ & $\begin{array}{l}210 \\
170 \\
210 \\
240 \\
240 \\
100 \\
170 \\
50 \\
850 \\
800 \\
200 \\
300 \\
230 \\
250\end{array}$ & $10 \mathrm{cc}$. blool oblained & $\begin{array}{c}\text { a little poor } \\
\text { poor } \\
\text { a little poor } \\
\text { poor } \\
" " \\
\text { good } \\
\text { poor } \\
\text { good } \\
\text { a little poor } \\
",\end{array}$ & $\begin{array}{c}\text { normal cons., little } \\
\text { tirm, little } \\
\text { soft, plentiful } \\
\text { normal cons., plentiful } \\
\text { soft, plentiful } \\
\text { ", } \\
\text { normal cons., plentiful } \\
\text { normal cons., little } \\
\text { normal cons., plentiful } \\
\text { no feces } \\
", \\
", \\
",\end{array}$ \\
\hline
\end{tabular}

Rabbit No. 4.

Table

\begin{tabular}{|c|c|c|c|c|c|c|}
\hline \multirow[b]{2}{*}{$\begin{array}{l}\text { Date } \\
1927\end{array}$} & \multirow{2}{*}{$\begin{array}{l}\text { Body- } \\
\text { weight } \\
\text { gm. }\end{array}$} & \multirow{2}{*}{ Diet } & \multirow{2}{*}{ Treatment } & \multirow[b]{2}{*}{ Appetite } & Feces & \\
\hline & & & & & $\begin{array}{c}\text { Consistence, } \\
\text { rolume }\end{array}$ & $\begin{array}{l}\text { Volume } \\
\text { cc. }\end{array}$ \\
\hline $\begin{array}{l}25.1 . \\
26 . \quad " \\
27 . \quad, \\
28 . \quad " \\
29 . \quad " \\
20 . \quad " \\
31 . \quad,\end{array}$ & $\begin{array}{l}2246 \\
2208 \\
2192 \\
2250 \\
2218 \\
2196 \\
2244\end{array}$ & $\mid \begin{array}{c}\text { lees of } \\
\text { beancurax } \\
" \\
" \\
" \\
" \\
"\end{array}$ & $\begin{array}{l}10 \% \text { uranium acet. } \\
0.5 \mathrm{ccs} . \mathrm{c} \text {. }\end{array}$ & $\begin{array}{c}\text { a litte pour } \\
", \\
" \\
\text { goox } \\
\text { a little poor }\end{array}$ & 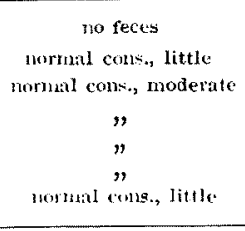 & $\begin{array}{l}150 \\
140 \\
140 \\
550 \\
170 \\
180 \\
195\end{array}$ \\
\hline 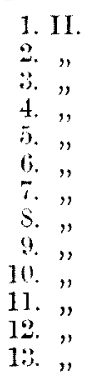 & $\begin{array}{l}2170 \\
2184 \\
2110 \\
2158 \\
2110 \\
2082 \\
2052 \\
1936 \\
1840 \\
1830 \\
1732 \\
1618 \\
1546\end{array}$ & $\begin{array}{l}", \\
", \\
", \\
", \\
", \\
", \\
" \\
", \\
",\end{array}$ & $\begin{array}{l}10 \text { re. blowl } \\
\text { ribtined }\end{array}$ & $\begin{array}{l}\text { puror } \\
", \\
", \\
" \\
" \\
" \\
" \\
" \\
" \\
" \\
"\end{array}$ & 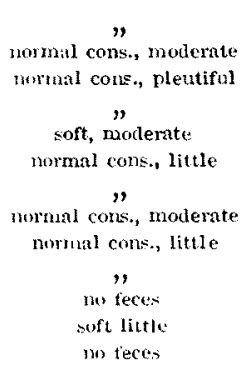 & $\begin{array}{r}130 \\
95 \\
\text { aumia } \\
85 \\
75 \\
40 \\
140 \\
130 \\
120 \\
75 \\
45 \\
55\end{array}$ \\
\hline
\end{tabular}




\section{XIII.}

\begin{tabular}{|c|c|c|c|c|c|c|c|c|}
\hline \multicolumn{4}{|c|}{ Crine } & \multicolumn{2}{|c|}{ Total amount of } & \multirow{2}{*}{$\begin{array}{l}\mathrm{Hb} \\
0\end{array}$} & \multirow{2}{*}{$\begin{array}{l}\text { Indican } \\
\text { in total } \\
\text { blood } \\
\text { mg. }\end{array}$} & \multirow{2}{*}{$\begin{array}{c}\text { Total amount } \\
\text { of indican in } \\
\text { urine \& blood } \\
\mathrm{mg} .\end{array}$} \\
\hline $\begin{array}{c}\text { Volume } \\
\text { cc. }\end{array}$ & $\underset{\text { bumin }}{A l-}$ & Blood & $\begin{array}{l}\text { Indican } \\
\text { mg. }\end{array}$ & $\begin{array}{l}\text { Blood } \\
\text { ce. }\end{array}$ & $\begin{array}{c}\text { Plasma } \\
\text { ce. }\end{array}$ & & & \\
\hline $\begin{array}{l}225 \\
165 \\
325 \\
315 \\
150 \\
200 \\
145\end{array}$ & - & - & $\begin{array}{l}0.7290 \\
0.9306 \\
0.2340 \\
0.1780 \\
0.4002 \\
0.4140 \\
0.8004\end{array}$ & 199 & 108 & 97.9 & 0.0194 & $\left.\begin{array}{l}1 \\
2 \\
3 \\
4 \\
5 \\
6 \\
7\end{array}\right\} 3.7056$ \\
\hline $\begin{array}{c}165 \\
135 \\
190 \\
100 \\
225 \\
250 \\
85 \\
120 \\
155 \\
100 \\
200 \\
175 \\
\text { anuria } \\
230\end{array}$ & $\begin{array}{c}++ \\
+++ \\
++ \\
++ \\
++ \\
+ \\
\text { trace }+ \\
\text { trace }+ \\
\pm \\
\pm \\
=\end{array}$ & - & $\begin{array}{r}1.0246 \\
0.3105 \\
0.1092 \\
0.2311 \\
0.8487 \\
0.2056 \\
0.1759 \\
0.7038 \\
0.5418 \\
0.2024 \\
1.1040 \\
0.9660 \\
0 \\
2.5656\end{array}$ & 191 & 108 & 97.9 & 0.0946 & $\left.\begin{array}{l}1 \\
2 \\
3 \\
4 \\
5 \\
6 \\
7 \\
1 \\
2 \\
3 \\
4 \\
5 \\
6 \\
7\end{array}\right\} .0287$ \\
\hline
\end{tabular}

XIV.

\begin{tabular}{|c|c|c|c|c|c|c|c|c|}
\hline \multicolumn{3}{|c|}{ Urine } & \multicolumn{2}{|c|}{ Total amount of } & \multicolumn{3}{|c|}{ Blood } & \multirow{2}{*}{$\begin{array}{l}\text { Total amount } \\
\text { of indican in } \\
\text { urine \& blood } \\
\text { mg. }\end{array}$} \\
\hline $\mathrm{pH}$ & $\underset{\text { bumin }}{\mathrm{Al-}}$ & $\begin{array}{l}\text { Indican } \\
\text { nig. }\end{array}$ & $\begin{array}{c}\text { Blood } \\
\text { ce. }\end{array}$ & $\begin{array}{c}\text { Plasma } \\
\text { ce. }\end{array}$ & $\mathrm{pII}$ & $\underset{\%}{\mathrm{Hb}}$ & $\begin{array}{c}\text { Indican } \\
\mathrm{mg} .\end{array}$ & \\
\hline $\begin{array}{l}8.45 \\
8.01 \\
8.57 \\
8.37 \\
8.39 \\
8.57 \\
8.42\end{array}$ & trace + & $\begin{array}{l}0.2836 \\
0.4586 \\
0.4468 \\
0.0624 \\
0.6854 \\
0.7560 \\
0.2444\end{array}$ & 182 & 91 & 7.56 & 92.8 & 0.0057 & $\left.\begin{array}{l}1 \\
2 \\
3 \\
4 \\
5 \\
6 \\
7\end{array}\right)_{2.9429}$ \\
\hline $\begin{array}{r}8.26 \\
7.66 \\
\\
7.68 \\
8.07 \\
10.18 \\
9.59 \\
9.34 \\
9.24 \\
9.24 \\
9.24 \\
9.54\end{array}$ & $\begin{array}{c}+ \\
++ \\
+++ \\
+++ \\
+++ \\
+++ \\
++ \\
+ \\
+ \\
+\end{array}$ & $\begin{array}{l}0.4914 \\
0.3024 \\
\\
0.1199 \\
0.1728 \\
0.2085 \\
0.6232 \\
0.5241 \\
0.3880 \\
0.9762 \\
0.6048 \\
0.9004\end{array}$ & 150 & 80 & 7.78 & 93.7 & $\begin{array}{c}(0.3207) \\
0.3207\end{array}$ & {$\left[\begin{array}{l}1 \\
2 \\
3 \\
4 \\
5 \\
6 \\
7 \\
1 \\
2 \\
3 \\
4 \\
5\end{array}\right]^{2.2389}$} \\
\hline
\end{tabular}


Rabbit No. 6.

\begin{tabular}{|c|c|c|c|c|c|}
\hline \multirow{2}{*}{$\begin{array}{l}\text { Dute } \\
1927\end{array}$} & \multirow{2}{*}{$\begin{array}{c}\text { Body- } \\
\text { weight } \\
\text { gnn. }\end{array}$} & \multirow{2}{*}{$\begin{array}{l}\text { Diet } \\
\text { gm. }\end{array}$} & \multirow{2}{*}{ Treatment } & \multirow{2}{*}{ Appetite } & Feces \\
\hline & & & & & $\begin{array}{l}\text { Consistence, } \\
\text { volume }\end{array}$ \\
\hline $\begin{array}{l}3 . \text { III. } \\
4 . \quad, \\
5 . \quad " \\
6 . \quad " \\
7 . \quad " \\
8 . \quad " \\
9 . \\
10 . \quad ",\end{array}$ & $\begin{array}{l}1630 \\
1600 \\
1606 \\
1606 \\
1600 \\
1624 \\
1644 \\
1660\end{array}$ & $\begin{array}{c}\text { lees of } \\
\text { bean } \\
\text { curds } 300 \\
300 \\
300 \\
300 \\
300 \\
300 \\
300 \\
300\end{array}$ & $\begin{array}{c}10 \% \text { nranium acct } \\
0.5 \mathrm{ec} \text { s. c. }\end{array}$ & $\begin{array}{c}\text { good } \\
\text { " } \\
" \\
" \\
" \\
" \\
"\end{array}$ & $\begin{array}{l}\text { normal cons., plentiful } \\
\text { normal cons., moderate } \\
\text { normal cons., plentiful } \\
\text { normal cons., moderate } \\
\text { firm, moderate } \\
\text { firm, plentiful } \\
\text { ", }\end{array}$ \\
\hline $\begin{array}{l}11 ., " \\
12 ., " \\
13 . ", \\
14 . ", \\
15 . ", \\
16 . ", \\
17 . ",\end{array}$ & $\begin{array}{l}1680 \\
1652 \\
1686 \\
1610 \\
1434 \\
1270 \\
1152\end{array}$ & $\begin{array}{r}240 \\
60 \\
20 \\
20 \\
50 \\
10\end{array}$ & $\begin{array}{c}10 \mathrm{cc} \text { blomi obtained } \\
\text { died }\end{array}$ & $\begin{array}{c}\text { a little poor } \\
\text { very poor } \\
\text { " } \\
" \\
" \\
" \\
"\end{array}$ & $\begin{array}{l}\text { firm, moderate } \\
\text { diarrhea, plentiful } \\
\text { diarrhea, little } \\
\text { no feces }\end{array}$ \\
\hline
\end{tabular}

Rabbit No. 10.

\begin{tabular}{|c|c|c|c|c|c|}
\hline \multirow{2}{*}{$\begin{array}{l}\text { Date } \\
1927\end{array}$} & \multirow{2}{*}{$\begin{array}{l}\text { Body- } \\
\text { weight } \\
\text { gm. }\end{array}$} & \multirow[b]{2}{*}{$\begin{array}{l}\text { Diet } \\
\text { gm. }\end{array}$} & \multirow[b]{2}{*}{ Treatment } & \multirow[b]{2}{*}{ Appetite } & Feces \\
\hline & & & & & $\begin{array}{l}\text { Consistence, } \\
\text { volume }\end{array}$ \\
\hline 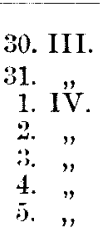 & $\begin{array}{l}2134 \\
2114 \\
2075 \\
2107 \\
2105 \\
2102 \\
2120\end{array}$ & $\begin{array}{c}\text { lees of } \\
\text { be:t11 } \\
\text { curts } 300 \\
300 \\
260 \\
300 \\
300 \\
300 \\
300\end{array}$ & 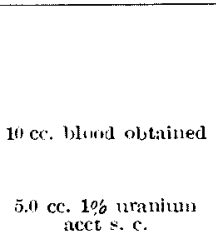 & $\begin{array}{c}\text { good } \\
\text { " } \\
" \\
" \\
" \\
"\end{array}$ & $\begin{array}{l}\text { normal cons., little } \\
\text { normal cons., moderate } \\
\text { firm, moderate } \\
\text { firm, plentiful } \\
\text { no feces } \\
\text { " } \\
\text { normal cons., moderate }\end{array}$ \\
\hline $\begin{array}{r}6 . \quad " \\
7 . \quad " \\
8 . \\
9 . \quad " \\
10 . \quad " \\
11 . \quad " \\
12 . \quad " \\
13 . \quad " \\
14 . \quad "\end{array}$ & $\begin{array}{l}2084 \\
2102 \\
2206 \\
2142 \\
2126 \\
2000 \\
2000 \\
1910 \\
1830\end{array}$ & $\begin{array}{r}240 \\
160 \\
40 \\
90 \\
20 \\
70 \\
10 \\
30\end{array}$ & $\begin{array}{l}10 \mathrm{ce} \text { blowl obtained } \\
\text { died }\end{array}$ & $\begin{array}{c}\text { a little poor } \\
\text { very poor } \\
\text { " } \\
" \\
" \\
" \\
"\end{array}$ & $\begin{array}{c}\text { normal cons., little } \\
\text { no feces } \\
\text { normal cons., plentiful } \\
\text { softer, plentiful } \\
\text { "" } \\
\text { softer, moderate } \\
\text { softer with blood, plent. } \\
\text { softer with blood, moder. }\end{array}$ \\
\hline
\end{tabular}


XV.

\begin{tabular}{|c|c|c|c|c|c|c|c|}
\hline \multicolumn{3}{|c|}{ Urine } & \multicolumn{2}{|c|}{ Total amount of } & \multirow{2}{*}{$\begin{array}{l}\text { IIb. } \\
0_{0}\end{array}$} & \multirow{2}{*}{$\begin{array}{l}\text { Indican } \\
\text { in total } \\
\text { blood } \\
\text { mg. }\end{array}$} & \multirow{2}{*}{$\begin{array}{c}\text { Total anount } \\
\text { of indican in } \\
\text { urine \& blood } \\
\text { ug. }\end{array}$} \\
\hline $\begin{array}{l}\text { Volume } \\
\text { e. }\end{array}$ & Albumin & $\begin{array}{l}\text { Indicun } \\
\text { mg. }\end{array}$ & $\begin{array}{l}\text { Blood } \\
\text { ec. }\end{array}$ & $\begin{array}{c}\text { Plasma } \\
\text { ee. }\end{array}$ & & & \\
\hline $\begin{array}{l}255 \\
175 \\
220 \\
245 \\
145 \\
195 \\
160 \\
145\end{array}$ & & $\begin{array}{l}0.5038 \\
0.5320 \\
0.5434 \\
0.3087 \\
0.3654 \\
0.6739 \\
1.2441 \\
0.4935\end{array}$ & 130 & 74 & 97.9 & $\begin{array}{l}0.0111 \\
(0.0111)\end{array}$ & $\left.\begin{array}{l}1 \\
2 \\
\because \\
4\end{array}\right) .2 .780$ \\
\hline $\begin{array}{c}16 \bar{y} \\
\text { anuria } \\
\text { anuria } \\
100 \\
\text { casted away } \\
100\end{array}$ & $\begin{array}{l}++ \\
++ \\
++\end{array}$ & $\begin{array}{l}0.0235 \\
0.3910 \\
1.2328\end{array}$ & 134 & 73 & 102.1 & $\begin{array}{c}0.1195 \\
(0.8728) \\
0.8728\end{array}$ & $\left.\begin{array}{l}1 \\
3 \\
3 \\
4\end{array}\right)$ \\
\hline
\end{tabular}

XVI.

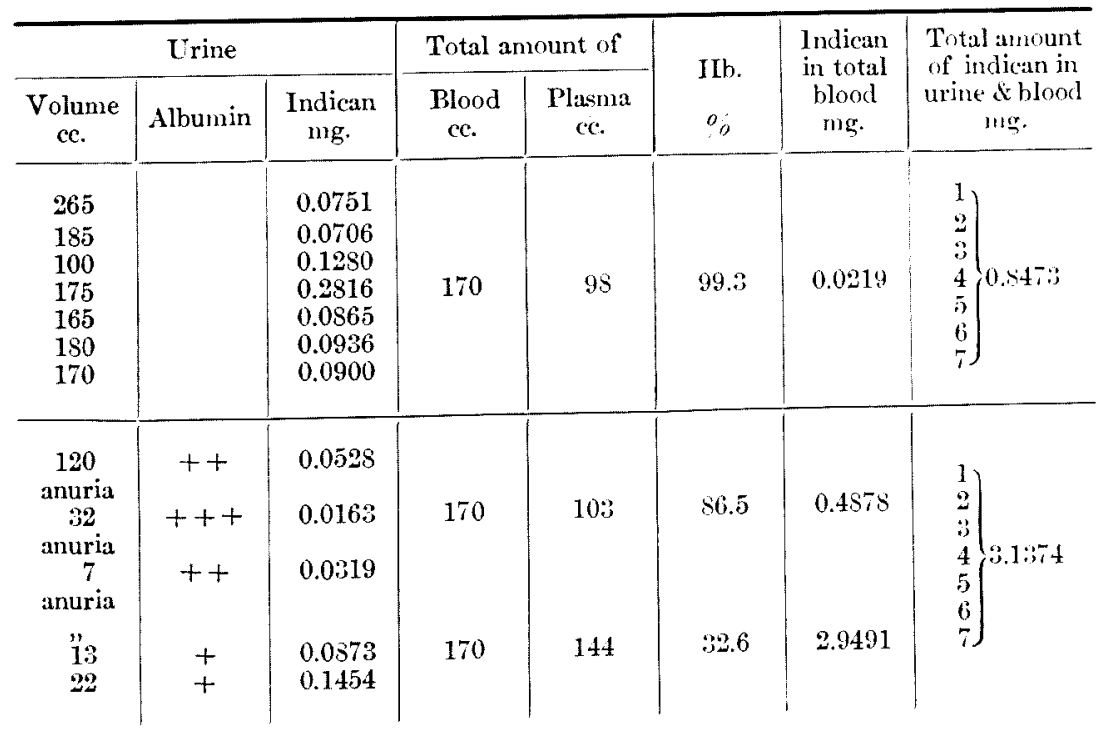


which was to be excreted in urine. Then did the increase of indican formation not take part in it? This question may be answered as follows. The total amount of indican in urine and blood during seven days before injection of uran, that is, the amount of indican which may be regarded as the total amount of indican formed during seven days before injection of uran, was compared with that of after injection of uran, and the figure $3.7056: 3.0287 \mathrm{mg}$. was calculated. If we conclude from this figure only, we may say that in the early stadium of nephritis there is no increase of indican formation, and the increase of indican in blood thereby may be the result of retention. But it can not be said without hesitation; because in the carly stadium the appetite decrensed very much, and it is a fact that the more the appetite decreases, the more the indican formation increases; further because even in the late stadium, when the appetite improved nearly to normal, the amount of indican increased to about two times as much as that of normal. We wonder how much more it would have been in the early stadium?

In the case of table XVI the indican in urine in the early stadium similarly decreased, but the total amount in blood and urine during seven days after injection of uran was larger than that in the normal state, namely, the result differed from those of other cases. If we search for the source of the different result, we may be able to find it with case. In this case the amount of hemoglobin decreased extraordinarily, and the amount of plasma increascd excedingly, that is, a strong hydremic state was observed. On this account the indican in blood in this case increased very much in comparison with other cases as we see in the table, and this is the reason why this case differed from other cases.

From these experiments it may be said that in uran nephritis the total amount of indican in urine and blood is, as a rule, less than that in the normal state. But it is quite another question, whether in uran nephritis the formation of indican decreases or not, because it may be improper in nephritis to regard the total amount of indican in urine and blood as the total sum of produced indican, for in nephritis indican is retained not only in blood, but also in the tissues and organs, and moreover it may be excreted vicariously from the digestive tube.

Fecheris examined indinan in the tissues in a nephrectomized dog and found that the total amount of indican in the muscles, heart, liver, spleen, brain, lungs and intestine was somewhat larger than that in the total amount of blood, and concluded that the indican was retained mainly in blood. But his calculation must be corrected, because the amount of indican in serum was calculated as the amount of indican in the equal volume of blood, and further his so-called indican in the tissues was in reality the indican in the tissues of $61 \%$ of 
the body weight. So in a word the amount of indicun retained in the body of nephrectomized dog may reach a much higher total than his calculation. By his experiment it is bard to compare the amount of indican formed in nephrectomized dog with that in normal dog. But we owe much to his studies, as we have learned that indican is not prored in the tissues in the normal and hunger state of animals.

Recently Steinit $\mathrm{z}^{34}$ ) observed the increase of residual nitrogen in the gastric juice by renal insufficiency, and attributed it to the action of the stomach as a vicarious organ. I considered that indican also might be excreted from the digestive tube by renal insufficiency. Then the feces in uran nephritis was examined for indican, and as it had been expected, indican reaction was positive in the feces in time of nephritis, whereas it was negative in the normal feces. Next the contents of stomach and the intestine of rabbit with renal insufficiency were examined for indican, and it was proved that they also contained indican in them.

Indican in the gastric juice and feces has been conceived by none "u this time: the studies on this subject may be reported later.

All things considered, in nephritis indican is not only retained in blood and tissues, but in the advanced stage it is excreted vicariously from the digestive tube.

In view of these facts, though in my experiment of uran nephritis the total amount of indican in urine and blood was smaller than that in the normal state, it does not mean the decrease of indican formation. In nephritis the total amount of produced indican should be determined, having estimated not only the amount of indican in urine and blood, but also the amount retained in the tissues and excreted from the digestive tube. Now it is $m y$ conviction that the indican formation may increase in nephritis.

\section{b. In nephritis due to habu-poison.}

Nomadays it is generally recognized that habu-poison acts on the blood and blood-vessels and causes bleeding in the tissues and organs and glomerulonephritis in the kidney.

This experiment was made for the purpose of examining whether there may be any difference or not between the uran nephritis and the nephritis due to habu-poison, namely, between nephrasis and glomerulonephritis, on the indican formation.

For experiment white rabbits of some tro kilograms' weight rere used. $0.003-0.004 \mathrm{gr}$. of habu-poison were subdermally administered. The result is mentioned in tables XVII, XVIII, XIX.

We may see from table XVII that during several days after injection of the poison the rabbit showed loss of appetite, gradually decrease of body weight, decrease of amount of urine and no change in the character of feces. Albumin in urine was observed only on the fourth day after in- 
Rabbit No. 4.

\begin{tabular}{|c|c|c|c|c|c|}
\hline \multirow{2}{*}{$\begin{array}{l}\text { Date } \\
1927\end{array}$} & \multirow{2}{*}{$\begin{array}{c}\text { Body- } \\
\text { weight } \\
\text { gm. }\end{array}$} & \multirow{2}{*}{$\begin{array}{l}\text { Diet } \\
\text { gn. }\end{array}$} & \multirow[b]{2}{*}{ Treatment } & \multirow[b]{2}{*}{ Appetite } & Feces \\
\hline & & & & & $\begin{array}{c}\text { Consistence, } \\
\text { volume }\end{array}$ \\
\hline $\begin{array}{l}\text { 17. IV. } \\
18 . ", \\
19 . ", \\
20 . ", \\
21 . ", \\
22 . ",\end{array}$ & $\begin{array}{l}2294 \\
2310 \\
2410 \\
2420 \\
2470 \\
2387\end{array}$ & 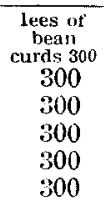 & 1) $\mathrm{cc}$. blood obtained & $\begin{array}{l}\text { gnod } \\
", \\
", \\
",\end{array}$ & $\begin{array}{c}\text { no feces } \\
\text { firm, moderate } \\
\text { firm, plentiful } \\
\text { firm, noderate } \\
\text { " }\end{array}$ \\
\hline 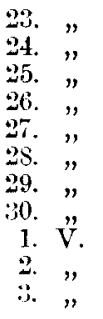 & $\begin{array}{l}2406 \\
2304 \\
2290 \\
2186 \\
2200 \\
2240 \\
2280 \\
2278 \\
2182 \\
2238 \\
2220\end{array}$ & $\begin{array}{r}0 \\
20 \\
60 \\
105 \\
170 \\
205 \\
240 \\
270 \\
300 \\
300 \\
300\end{array}$ & 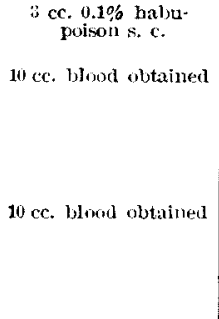 & 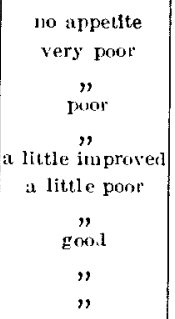 & $\begin{array}{c}\text { firm, little } \\
\text { firm, moderate } \\
\text { normal cons., plentiful } \\
\text { no feces } \\
\text { firm, little } \\
\text { normal cons, moderate } \\
\text { firm, plentiful } \\
\text { normal cons., moderate } \\
\text { normal cons., plentiful } \\
\text { normal cons., moderate }\end{array}$ \\
\hline
\end{tabular}

Rabbit No. 9.

\begin{tabular}{|c|c|c|c|c|c|}
\hline \multirow{2}{*}{$\begin{array}{l}\text { Date } \\
1727\end{array}$} & \multirow{2}{*}{$\begin{array}{c}\text { Body- } \\
\text { wejght } \\
\text { gm. }\end{array}$} & \multirow{2}{*}{$\begin{array}{l}\text { Diet } \\
\text { gm. }\end{array}$} & \multirow{2}{*}{ Treatment } & \multirow{2}{*}{ Appetite } & Feces \\
\hline & & & & & $\begin{array}{l}\text { Consistence, } \\
\text { volume }\end{array}$ \\
\hline $\begin{array}{l}\text { 4. IV. } \\
5 . ", \\
6 . ", \\
7 ., " \\
8 ., "\end{array}$ & $\begin{array}{l}1960 \\
1962 \\
1942 \\
1990 \\
1956\end{array}$ & 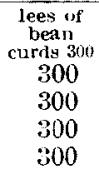 & $10 \mathrm{cc}$. blood obtained & $\begin{array}{c}\text { good } \\
", \\
" \\
"\end{array}$ & $\begin{array}{c}\text { normal cons., plentiful } \\
\text { " } \\
", \\
",\end{array}$ \\
\hline $\begin{aligned} 9 . & " \\
10 . & " \\
11 . & " \\
12 . & " \\
13 . & " \\
14 . & "\end{aligned}$ & $\begin{array}{l}1984 \\
1936 \\
1906 \\
1748 \\
1622 \\
1586\end{array}$ & $\begin{array}{l}30 \\
30 \\
70 \\
70 \\
30\end{array}$ & $\begin{array}{l}\text { sc. 0.1\% hatbu- } \\
\text { poison s. c. } \\
10 \mathrm{cc} \text {. blowal obtained }\end{array}$ & $\begin{array}{c}\text { very poor } \\
\text { " } \\
" \\
" \\
"\end{array}$ & $\begin{array}{c}\text { normal cons, moderate } \\
\text { diarrhea, plentiful } \\
\text { soft, little } \\
\text { no feces } \\
"\end{array}$ \\
\hline
\end{tabular}

jection, hematuria was never noticed. As to the change of blood, the increase of the amount of plasma and the decrease of the amount of hemoglobin were observed. And as to the amount of indican it increased very 
XVII.

\begin{tabular}{|c|c|c|c|c|c|c|c|c|}
\hline \multicolumn{4}{|c|}{ Urine } & \multicolumn{2}{|c|}{ Total amount of } & \multirow{2}{*}{$\begin{array}{c}\mathrm{Hb} . \\
\%\end{array}$} & \multirow{2}{*}{$\begin{array}{l}\text { Indican } \\
\text { in total } \\
\text { blood } \\
\text { mg. }\end{array}$} & \multirow{2}{*}{$\begin{array}{c}\text { Total amount } \\
\text { of indican in } \\
\text { urine \& blood } \\
\text { mg. }\end{array}$} \\
\hline $\begin{array}{c}\text { Volume } \\
\text { ce. }\end{array}$ & $\underset{\text { bumin }}{\mathrm{Al}-}$ & Blood & $\begin{array}{l}\text { Indican } \\
\text { mg. }\end{array}$ & $\begin{array}{c}\text { Blood } \\
\text { ce. }\end{array}$ & $\begin{array}{c}\text { Plasma } \\
\text { ce. }\end{array}$ & & & \\
\hline $\begin{array}{r}220 \\
85 \\
185 \\
190 \\
305 \\
215\end{array}$ & & & $\begin{array}{l}0.2508 \\
0.2054 \\
0.2504 \\
0.2368 \\
0.2688 \\
0.4414\end{array}$ & 189 & 91 & 102.1 & 0.0090 & $\left.\begin{array}{l}1 \\
2 \\
3 \\
4 \\
5 \\
6\end{array}\right\} 1.6620$ \\
\hline $\begin{array}{c}\text { anuria } \\
\not ̋ \\
100 \\
60 \\
75 \\
110 \\
165 \\
185 \\
150 \\
240 \\
185\end{array}$ & $\begin{array}{c}- \\
\text { trace } \\
- \\
- \\
- \\
-\end{array}$ & $\begin{array}{l}- \\
- \\
- \\
-\end{array}$ & $\begin{array}{r}0 \\
0 \\
4.6720 \\
1.6819 \\
3.6135 \\
2.3588 \\
1.8308 \\
0.8373 \\
0.4489 \\
0.3591 \\
0.1890\end{array}$ & 177 & 113 & 86.8 & $\begin{array}{c}0.0765 \\
(0.0094) \\
0.0094\end{array}$ & $\left.\begin{array}{l}1 \\
2 \\
3 \\
4 \\
5 \\
6\end{array}\right\} 12.8856$ \\
\hline
\end{tabular}

\section{XVIII.}

\begin{tabular}{|c|c|c|c|c|c|c|c|c|}
\hline \multicolumn{4}{|c|}{ Urine } & \multicolumn{2}{|c|}{ Total amount of } & \multirow{2}{*}{$\begin{array}{l}\text { Hb. } \\
\%\end{array}$} & \multirow{2}{*}{$\begin{array}{l}\text { Indican } \\
\text { in total } \\
\text { blood } \\
\text { mg. }\end{array}$} & \multirow{2}{*}{$\begin{array}{c}\text { Total amount } \\
\text { of indican in } \\
\text { urine \& blood } \\
\text { mg. }\end{array}$} \\
\hline $\begin{array}{c}\text { Volume } \\
\text { ce. }\end{array}$ & $\underset{\text { bumin }}{\mathrm{Al}-}$ & Blood & $\begin{array}{l}\text { Indican } \\
\text { mg. }\end{array}$ & $\begin{array}{l}\text { Blood } \\
\text { ec. }\end{array}$ & $\begin{array}{c}\text { Plasma } \\
\text { cc. }\end{array}$ & & & \\
\hline $\begin{array}{r}200 \\
85 \\
150 \\
165 \\
200\end{array}$ & & & $\begin{array}{l}0.3456 \\
0.0619 \\
0.3236 \\
0.1443 \\
0.1504\end{array}$ & 159 & 88 & 102.1 & 0.0098 & $\left.\begin{array}{l}1 \\
2 \\
3 \\
4\end{array}\right\} 0.6900$ \\
\hline 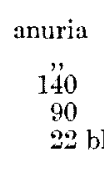 & $\begin{array}{l}\text { trace }+ \\
\text { trace }+ \\
\text { ue urine }\end{array}$ & - & $\begin{array}{r}0 \\
0 \\
2.7888 \\
3.6864\end{array}$ & 142 & 86 & 86.8 & 0.1513 & $\left.\begin{array}{l}1 \\
2 \\
3 \\
4\end{array}\right\} 6.6265$ \\
\hline
\end{tabular}

much in urine and a little in blood. This may have resulted from only a small part of the produced indican having remained, while most of it has been eliminated into urine on account of the slight degree of the renal 


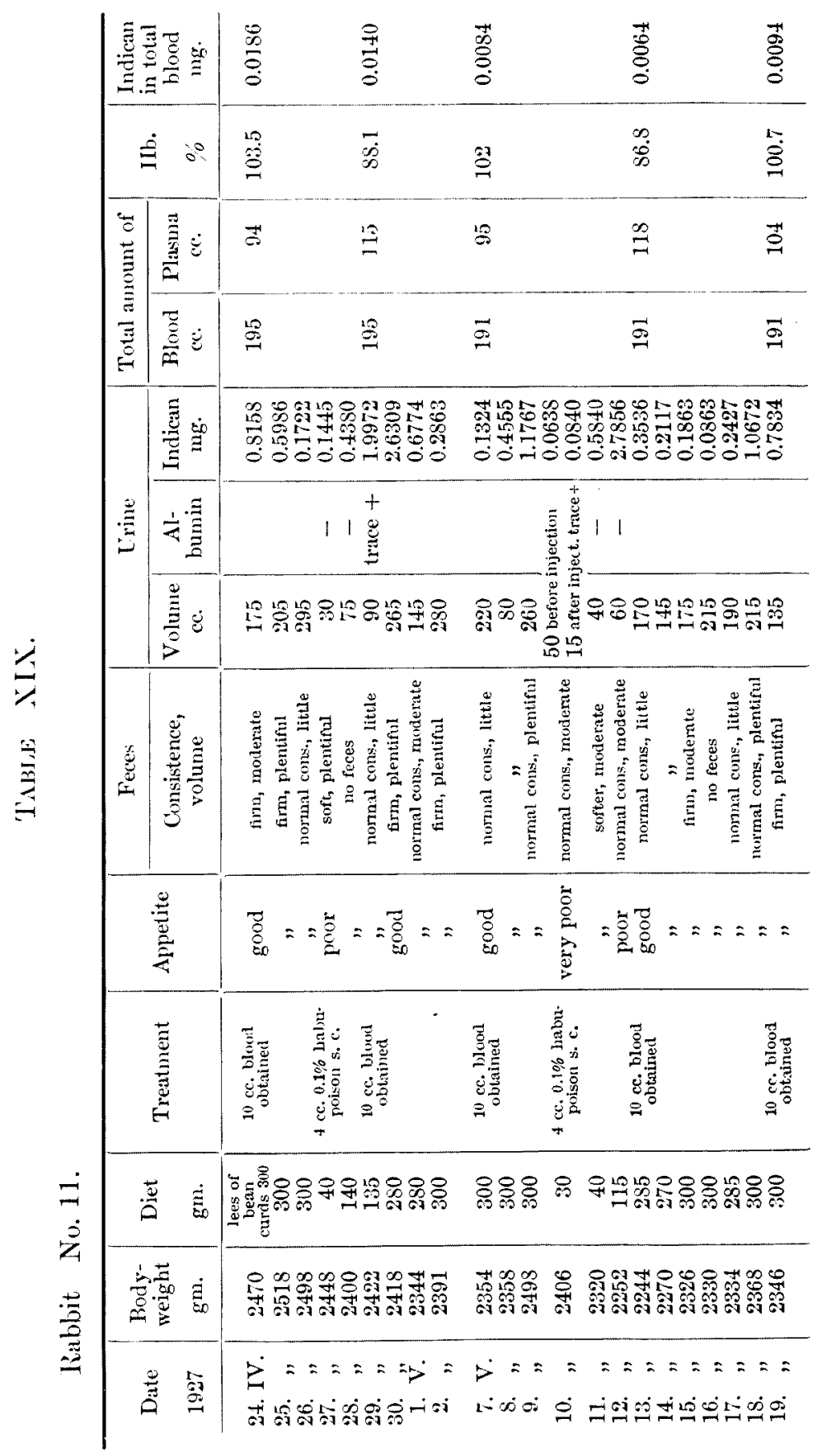


insufficiency, and the total of indican in urine and blood accounted to scveral times as much as that in the normal state.

As we see in table XVIII, in this case a similar result was obtained. In the case of table XIX the degree of renal insufficiency was so very slight that no retention of indican was observed.

Now, if we compare the uran nephritis and the nephritis due to habupoison on the distribution of indican, we may find that the amount of indican in blood is large in the former, and that in urine is large in the latter. If we judge from this account only, it seems that the distribution of indican in urine and blood varies with the form of nephritis, yet it may not be due to the difference of form, but it may be due to the difference of the degree of renal insufficiency ; that is, in uran nephritis the renal insufficiency was so strong that the indican to be exceted was retained in blood, whereas in nephritis due to habu-poison the renal insufficiency was slight, and almost all the produced indican in the organism could be eliminated through the kidney. This caused the difference of the distribution of indiean in these two nephritides.

If that be the case, how is indican formed in these nephritides? As has already been discussed, though it seems apparently that in uran nephritis the formation of indican decreases, yet it must be considered that in reality it may increase. In nephritis due to habu-poison it is cvident that there is an increase of the indican formation.

Hereupon I have reached the next conclusion. The hyperindicanemia observed in nephritis is the result of increased formation of indican in addition to the retention of indican in blood.

\section{The Influence of the Discharge of Feces by I a xative on the Indican Formation.}

If indicanuria is caused by flourishing putrefaction in the digestive tube, indican in urine would disappear or decrease, if the intestinal contents are discharged rapidly or prevented from putrefaction. I have experienced in one case shown in table III that indienn never decreased, but rather increased by preventing the putrefaction in the intestinal canal with calomel. This time I tried to see the influence of the discharge of feces on the indican formation.

Rabbits with some two kilograms of body weight were used for experiment. As laxative magnesium sulfuricum and oleum ricini were used. At first $20,40,60,80$ c.c. of $10 \%$ magnesium sulfate solution were introduced with a stomach-tube into rabbits, but any change of the character of feces, of appetite, or of indican was not observed at any time. Then oleum 
ricini was administered per os, and a large amount of soft or loose feces was discharged. The results are mentioned in table $\mathrm{XX}, \mathrm{XXI}, \mathrm{XXII}$.

10-15 c.c. of oleum ricini and an equal volume of water were administered per os to rabbits weighing 1.5-2 kilos. In each case soft feces or diarrhea followed, and loss of appetite and decrease of booy weight continued during several days after the administration. As to indican it increased very much, and it continued as long as the loss of appetite, namely, as Jong a" the decrease of body weight continued.

Rabbit No. 15.

Tabie XX.

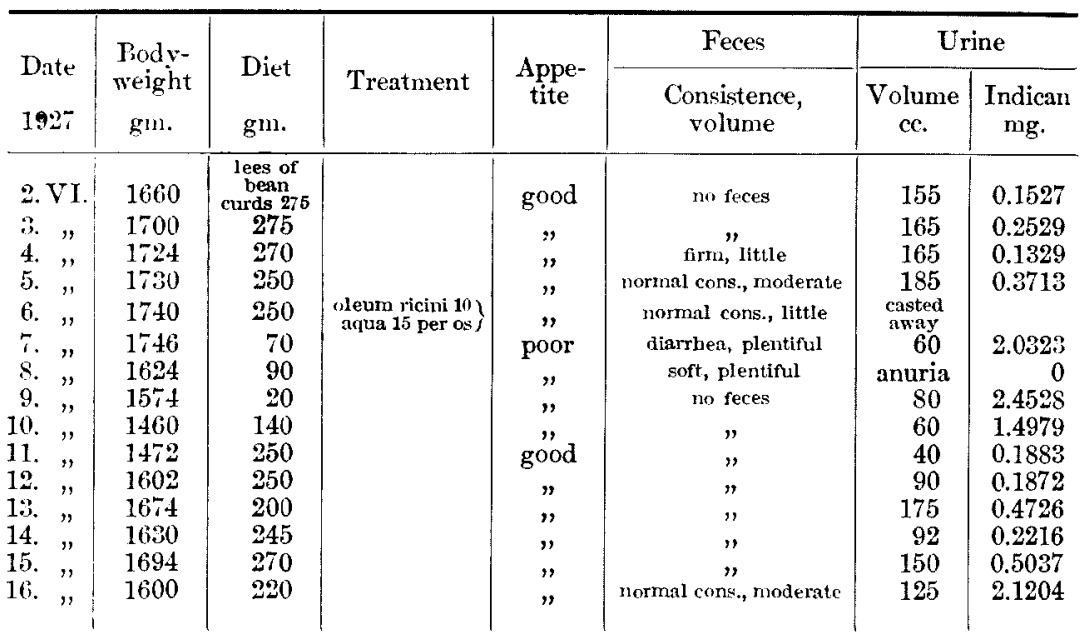

Table XXI.

Pabbit No. 16.

\begin{tabular}{|c|c|c|c|c|c|c|c|}
\hline \multirow{2}{*}{$\begin{array}{l}\text { Date } \\
1927\end{array}$} & \multirow{2}{*}{$\begin{array}{l}\text { Pody- } \\
\text { weight } \\
\text { gm. }\end{array}$} & \multirow[b]{2}{*}{$\begin{array}{l}\text { Diet } \\
\text { gm. }\end{array}$} & \multirow[b]{2}{*}{ Treatment } & \multirow{2}{*}{$\begin{array}{l}\text { Appe- } \\
\text { tite }\end{array}$} & Feces & \multicolumn{2}{|c|}{ Urine } \\
\hline & & & & & $\begin{array}{c}\text { Consistence, } \\
\text { volume }\end{array}$ & $\begin{array}{l}\text { Volume } \\
\text { cc. }\end{array}$ & $\begin{array}{l}\text { Indican } \\
\text { mg. }\end{array}$ \\
\hline 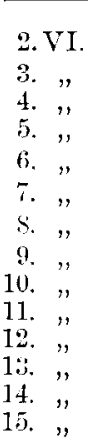 & $\begin{array}{l}2070 \\
2026 \\
2024 \\
2016 \\
2046 \\
2060 \\
1924 \\
1870 \\
1832 \\
1770 \\
1510 \\
1978 \\
1946 \\
1960\end{array}$ & 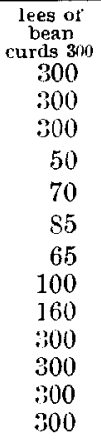 & $\left.\begin{array}{r}\text { oleum ricini 10) } \\
\text { aqua } 15\} \\
\text { olewn ricini } 10 \\
\text { aqua } 15\end{array}\right\}$ & $\begin{array}{c}\text { good } \\
" \\
" \\
" \\
\text { very poor } \\
" \\
" \\
" \\
\text { poor } \\
" \\
\text { gool } \\
, " \\
" \\
"\end{array}$ & $\begin{array}{c}\text { normal cons., moderate } \\
\text { normal cons., plentiful } \\
\text { fin m, plentiful } \\
\text { nom, little } \\
\text { no feces } \\
", \\
\text { soft, moderate } \\
\text { "" } \\
\text { nornitl cons., little } \\
\text { "" feces } \\
\text {," } \\
\text { firm, little } \\
\text { normal cons, plentiful }\end{array}$ & $\begin{array}{c}240 \\
165 \\
195 \\
185 \\
\text { anuria } \\
120 \\
30 \\
\text { anuria } \\
72 \\
82 \\
110 \\
180 \\
195 \\
170\end{array}$ & $\begin{array}{r}0.2968 \\
0.6504 \\
0.3558 \\
0.2308 \\
0 \\
7.2584 \\
1.9710 \\
0 \\
5.0457 \\
1.7718 \\
0.1124 \\
0.1314 \\
0.1281\end{array}$ \\
\hline
\end{tabular}


Rabbit No. 17.

\section{Tabie xxil.}

\begin{tabular}{|c|c|c|c|c|c|c|c|}
\hline \multirow{2}{*}{$\begin{array}{l}\text { Date } \\
1927\end{array}$} & \multirow{2}{*}{$\begin{array}{l}\text { Body- } \\
\text { weight } \\
\text { gin. }\end{array}$} & \multirow{2}{*}{$\begin{array}{l}\text { Diet } \\
g m .\end{array}$} & \multirow{2}{*}{ Treatment } & \multirow{2}{*}{$\begin{array}{l}\text { Appe- } \\
\text { tite }\end{array}$} & Feces & \multicolumn{2}{|c|}{ Lrine } \\
\hline & & & & & $\begin{array}{c}\text { Consistence } \\
\text { volume }\end{array}$ & $\begin{array}{c}\text { Volume } \\
\text { ce. }\end{array}$ & $\begin{array}{l}\text { Indican } \\
\text { mg. }\end{array}$ \\
\hline 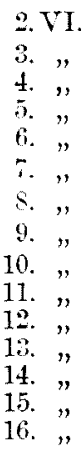 & $\begin{array}{l}1874 \\
2020 \\
1922 \\
1864 \\
1590 \\
1912 \\
1910 \\
1510 \\
1658 \\
1646 \\
1520 \\
1492 \\
1466 \\
1408 \\
1.444\end{array}$ & $\begin{array}{c}\text { lees of } \\
\text { beancurds } \\
300 \\
300 \\
270 \\
250 \\
140 \\
165 \\
105 \\
65 \\
50 \\
110 \\
80 \\
110 \\
160 \\
130\end{array}$ & $\begin{array}{r}\text { olem ricini } 10 \\
\text { aqua } 15\end{array}$ & 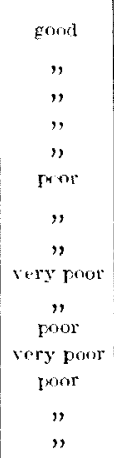 & 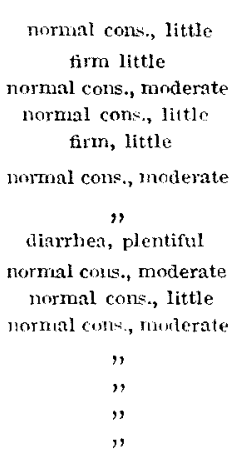 & $\begin{array}{c}\text { anuria } \\
215 \\
235 \\
185 \\
110 \\
\text { anuria } \\
120 \\
42 \text { feces } \\
\text { mixed } \\
\text { anuria } \\
100 \\
52 \\
38 \\
50 \\
37 \\
30\end{array}$ & $\begin{array}{l}0.5499 \\
0.5661 \\
0.3713 \\
0.2810 \\
\\
2.9433 \\
0.6990 \\
\\
2.3860 \\
1.0325 \\
0.9986 \\
2.8032 \\
2.9711 \\
2.4090\end{array}$ \\
\hline
\end{tabular}

From this point of view it seems that the discharge of feces did not act to docrease the indican, rather acted to increase it, but this is not the direct effect of the discharge of feces; it is the result of poor appetite due to the administration of the laxative. In fact the discharge or the stagnation of feces has no relation to the amount of indican.

I have learned from this experiment that the factor which increases or decreases the amount of indican is only the state of appetite; that is, if the appetite decreases, the amount of indican increases, and vice versa. This relation is so intimate that the decrease of the appetite and the increase of the amount of indican run quantitatively parallel. Therefore we may be able to presume the degree of loss of appetite, namely, the degree of the decrease of body weight, from the amount of indican.

\section{Discussion.}

I have already stated in the introductory paper that there are two theories concerning the indican formation. Here I will state my opinion based on the experiment.

(1) Distaso $0^{993}$ pointed out that when guinea-pigs are nourished with cabbages indican in urine disappears with the disappearence of bact. coli in fercs, and he claimed that the indican in urine is caused by the action of bart. coli in the intestine. According to my experiment, contrary to 
him, neither bact. coli nor indican disappeared in the feces respectively in the wine of guinea-pig nowished with cabbage. But in this case it was observed that the amount of urine of guinea-pigs nourished with cabbages was very voluminous, hence the amount of indican seemed similar to that in urine diluted with water.

(2) There is much disagreement about the influence of inanition on the indican formation as already described. In my experiment with rabbits and guinea-pigs the amount of indican increased always with no exception under the state of hunger. Ellinge $\mathbf{r}^{13}$ claimed that the increase of indican in inanition is due to the fact that the animal eats its stools, but my experiment proved his objection groundless. Müller ${ }^{5)}$ and Nencki $i^{(6)}$ insisted that the increase of indican in the state of hunger is due to the putrefaction of the pancreatic juice and the crumbled epitherial cells of the intestinal canal. But it seems impossible to explain by their view the increase of indican under only a few hours' fast. So I support the opinions, which Blumenthal and Rosenfeld ${ }^{11}$ have proposed that the increase of indican is caused by the decomposition of body protein due to hunger.

(3) Now let us consider what has caused the increased indican by the administration of liver or kidney cells. Though it may not be hard to explain the origin of the indican increased thereby by Miyaga wa's theory, yet it may be more conceivable that it is the result of decomposition of body protein due to injured appetite, i. e. to the incomplete inanition on account of poisoning by the administration of liver or kidney cells.

(4) It was known from the experiment that the amount of indican increases in nephritis. Now if we seek its cause thereby, we shall find that the increase of indican may have been caused by the crumbling of cells on account of the administration of uranium or habu-poison. But if we consider that the increase of indican was accompanied by a decrease of appetite, or when the appetite improved to normal the amount of indican also decreased to nearly normal, so it is more reasonable to regard the increase of indican as depending upon the poor appetite consequently resulting from increased decomposition of body protein.

(5) If we consider that the administration of medicaments, namely, calomel or oleum ricini, was always accompanied with loss of appetite, it is rather a natural consequence and not to be wondered that the animals, in which the digestive tube were disinfected with calomel or the intestinal contents were discharged rapidly with oleum ricini, excreted increased indican contrary to Baumann'sin findings. 
Hereupon I will take a glance at the researches of our predecessors. The representative of the theory of abacterial formation of indican, $\mathrm{Harn} \mathrm{ack}^{9)}$ obserred the increase of indican by the administration of sodium oxalate, Rosenbergii) by repeated injection of urea, and Blumenthal and Rosenfeldil by phlorhidzin-intoxication.

But they gave us no information on the state of appetite of observed animals. So it must be a question whether in their experiments the administrated medicaments caused the increase of indican, because my experiment showed the increase of indican whenever the appetite diminished. I have not observed increased indican by subcutaneous injection of 0.01-0.04 grm. of sodium oxalate to a guinea-pig weighing 400 . This agreed with the result of Scholz's experiment.

According to Moraczewskj10) the amount of indican and oxalic acid in urine ran parallel, and by the administration of soda their amount decressed, and thus the amount of indican raried depending upon the reaction of urine. But the result of my experiment differed as has been mentioned in table II. In another case, namely, in one of the cases of nephritis I estimated $p_{\mathrm{H}}$ of urine and blood and found that there is no relation between the amount of indican and the reaction of urine.

I shall now state my views on the clinical significance of indicanuria and indicanemia.

\section{A. Indicanuria.}

The disorders in which we frequently meet with indicanuria are as follows :

(1) Diseases of digestive system : acute and chronic gastro-intestinal catarrh, gastric ulcer, cholera nostras, cholera asiatica, acute and chronic diffuse peritonitis, hernia incarcerata, intestinal obstruction.

(2) Acute infectious diseases: pneumonia, meningitis, acute miliary tuberculosis, typhoid fever, pleuritis, scarlet fever, smallpox.

(3) Diseases of consumption : pulmonary tuberculosis, cancer of the stomach, carcinoma of the liver, lymphosarcoma, progressive muscular atrophy.

(4) Disorders of other origin : chlorosis, leucemia, anemia perniciosa, kidney disease, diabetes mellitus, beriberi, lead poisoning, trichinosis, Ad dison's disease, phlegmon, eczema, pregnancy, puerperium.

Besides these mentioned above there are too many to enumerate all of them.

Many investigators have sought the origin of indicanuria by these disorders, and some of them attributed it to the flourishing of putrefaction in the digestive tube. But unfortunately there are many cases which can not be interpreted by this view. For example, how can we explain the 
indicanuria in pneumonia, meningitis, anemia, diabetes mellitus? If one attributed the indicanuria in these disorders to the flourishing putrefaction in the digestive tube, it would be a far-fetched view. I believe that indicanuria in these disorders may well be taken as the result of diminished appetite, consequently as the result of the increased decomposition of body protein. As regards the indicanuria in the gastro-intestinal disturbances I have the same opinion, because my experiment showed that the amount of indican has no connection with the character of feces, diarrhea or constipation.

Indicanuria is not pathognomonic for any of the diseases; even in the same disease, in one case it appears, in another it does not. And I believe that the amount of indican increases more or less in every disease accompanied with loss of appetite; in other words, indicanuria is one of the signs of the increased decomposition of body protein. As regards the indicanuria in cases with no changes of appetite, it may be attributed to the increase or anomaly of metabolism.

Now if we see the diseases above mentioned, we shall find that in the greater part of them the decrease of appetite usually appears in high degree, otherwise the reduction of diet would be required for the treatment. Therefore it is very natural and reasomable that we see indicanuria in these disorders.

According to M. Dohi $\mathrm{i}^{\text {ins }}$ indicanuria appears in over one fourth of women in pregnancy and childbed. 'This may be attributed to the increased metabolism by pregnancy or puerperium, or to the decreased appetite due to pregnancy-toxicosis.

It is reported that in infants indicanuria is often brought about by slight disorder. This may be due to the next reason ; that the metabolism of an infant is physiologically in an increased state, so if slight disturbance occurs, the disorder of catabolic process may result easily.

Y a maguchi ${ }^{30)}$ reported that the putrefaction in the digestive tube may be the source of eczematous disposition of infants, because indicanuria was often observed in eczema of infants. I think that may come from the sanc cause as above, and his suspicion may be groundless.

\section{B. Indicanemia.}

As disorders in which we sec indicanemia, kidney disease and gastrointestinal disturbances etc. are to be mentioned. I have already stated that the indicancmia by renal insufficiency may be the result of increased 
formation as well as retention of indican. According to Beche ${ }^{33}$ indican is retained in blood ahead of other compounds by renal insufficiency ; my experiment has shown that the retained indican in blood in nephritis may be soon excreted into urine when the disease goes into convalescence. Therefore to determine the indican in blood in kidney disease may be not ouly necessary for the test of renal function, but also it may be a guide to presume prognosis.

Haas, ${ }^{3 i)}$ Rosenberg ${ }^{35)}$ and Ba a ${ }^{30 ;}$ found that indican in blood increases by gastro-intestinal disturbances. Ba ar has given ont a view that the indican increased thereby has no connection with the increased indican in urine. But I want to regard the indicanemia thereby as a partial appearence of increased formation of indican, because $I$ saw a slight increase of blood indican in a rabbit (Table VIII) suffering from diarrhea and in one case of inanition (Table IV), and in both cases the intican in urine jncreased intensively.

Shibayama $a^{40)}$ in our institute found that the blool of a fetus rontains more indican than that of the mother.

In such a way there may be many cases of indicanemia, but the degree of it is very low compared with the indicanemia in kidney disease. Thus indicanemia may well be said to be characteristic of kidney disease.

In conclusion of the discnssion I dare say that indican may be an intermediate product of body protein, and it may increase when the protein metabolism is out of order.

\section{Sumary.}

1. Bacterium coli in the intestine and indican in urine never disappear even when the guinea-pigs are nourished only with cabbages.

2. Indican in urine of guinea-pigs increases by only a few hours' fasting.

3. Indican in urine of rabbits does not at all decrease, rather increases about ten times as much as normal by ten days' fasting.

4. The amount of indican has no conncetion with the character of feces.

5. Between the indican formation and the state of appetite there is a very intimate relation; if the appetite decreases, the amount of indican increases, and vice versa, and it may well be said that the decrease of appetite and the increase of indican run quantitatively parallel.

6. The parenteral administration of a large anount of liver or kid- 
ney cells has caused the increased excretion of indican. But whether it may be due to the direct action of the constituents of the introduced cells, or to the poor appetite resulting from their administration is questionable.

7. In the early stage of the uran nephritis the total amount of indican in urine and blood is smaller than that of the normal state. But the total amount of indican formed thereby must be larger than that of the normal if we take into consideration the indican retained in the tissues and excreted vicariously into the digestive tube.

8. The hyperindicanemia in nephritis is the result of increased formation as well as retention of indican.

9. In habu-poison nephritis also the blood contains more indican than normal, and the total amount of indican in urine and blood is larger than that of the normal.

10. The disinfection of the intestinal canal or the rapid discharge of intestinal contents with medicaments does not diminish the amount of indican, but rather increases it.

11. The reaction of urine has no connection with the amount of indican.

12. The parenterally administered sodium oxalate has no influence on the indican formation in guinea-pigs.

13. Exccpt for the indicanemia in renal insufficiency we often meet slight indicanenia in various diseases, which may be regarded as a partial appearence of increased indican, for example, by gastro-intestinal disturbances or inanition.

14. Indican is excreted vicarionsly from the digestive tube in renal insufficiency.

15. The indicanuria observed clinically in many diseases may be attributed partly to the increased decomposition of body protein due to the poor appetite, and partly to the anomalies of metabolism.

16. Finally I have reached the next conclusion that indican may well be formed also through the metabolic process without the activity of bacteria.

In conclusion I wish to express my sincere thanks to Professor Dr. T. Ishikawa for his generous help, criticism and advice throughout the investigration.

\section{Bibliography.}

(1) XI. J a f fe, Pflüger's Arch. 1870, 3, 448.

(2) II. Jaffe, Virchow's Arch. 1877, 70, 78. 
(3) E. Salkowski, Berichte d. deut. chem. Gesell. 1876, 9, 408. $12,78$.

(4) F. Hoppe-Seyler, (W. Kuokol-Yasnopolsky), Pflüger's Arch. 1S76,

(5) Fr. Müller, Berl. klin. Wochenschr. J887, 438.

(6) Nencki, Centralbl. f. d. med. Wiss. 1878, 16, 609.

(7) E. Ba um an n, Zeitschr. f. physiol. Chem. 1886, 10, 123.

(8) Harley and Goodbody, Brit. Med. Journ. 1899, 2, 1254.

(9) Harnack and E. v. d. Le yen, Zeitschr. f. physiol. Chen. 1900, 29, 205.

(10) W. v. Moraczewski, Centralbl. f. innere Med. 1903, 24, 2.

(11) F. Bl umenthal and Rosenfeld, Charite-Annal. 1908. 27, 46.

(12) Lew in, Beitrag z. chem. Physiol. und Pathol. 1902, I, 427.

(13) H. Schol z, Zeitschr. f. physiol. Chem. 1903, 38, 513.

(14) A. Ellinger, Zeitschr. f. physiol. Chem. 1903, 39, 44.

(15) H. Popper, Zeitschr. f. klin. Med. 1911, 72, 332.

(16) A. Jolles, Zeitschr. f. physiol. Chem. 1913, 87, 310.

(17) M. Rosenberg, Arch. f. exp. Path. v. Pharm. 1916, 79, 265.

(18) F. Oberme yer, Wien. Wochenschr. 1890, 176.

(19) K. Takeuchi, Tokio Igakukai Zasshi, (Japan.) 1917, 31, 1199.

(20) A. Dist aso and J. Schiller, Comp. rend. Soc d. Biol. 1915, 78, 266. Ch. Porcher and Ch. Herveu x, Zeitschr. f. physiol. Chem. 1903, 39, 147.

(21) V. r. St an ford, Zeitschr. f. physiol. Chem. 1913, 87, 188.

(22) G. Hoppe-Seyler, Zeitschr. f. physiol. Chem. 1916, 97, 171.

(23) K. Kötschau, Klin. Wochensehr. 1926, 2405.

(24) A. Jolles, Zeitschr. f. Physiol, Chem. 1915, 94, 79.

(25) H. Strauss, Die Nephritiden. Berlin 1920, 93.

(26) Plesch, Methodik der Blutuntersuchung von Dom ar us, Berlin 1921, 127.

(27) Hedin, Ibid., 182.

(28) Gautier, Comp. rend. Soc. d. Biol. 1908, 44, 433.

(29) A. Dist a so, Comp. rend. Soc. Biol. 1924, 91, 61.

(30) Y. Mi yagawa, Scient. Reports from the Govern. Inst. for Infect. Dis. Tokyo, $1923,2,375$.

(31) K. Sakurabayashi, Tohoku Journ. of Exp, Med. 1925, 6, 390.

(32) G. H a as, Deut. Arch. f. klin. Med. 1917, I21, 304.

(33) E. Becher, Deut. Arch. f. klin. Med. 1919, 129, 8 .

(34) H. Steinitz, Klin. Wochenschr. 1927, 949.

(35) M. Dohi, Nippon Fujinka Gakukai Zasshi, (Japan.) 1920, 15, 322.

(36) F. Yamaguchi, Hifuka Hinyokika Zasshi, (Japan.) 1921, 21, 809.

(37) G. H a as, Deut. Arch. f. klin. Med. 1916, 119, 177.

(38) M. Rosenberg, Arch. f. Exp. Path. u. Pharmak. 1920, 86, 15.

(39) G. Baar, Die Indikanämie, Berlin 1922, 36.

(40) K. Shibay a ma, Japan. Journ. of Med. Sci., Biochem. 1926, I, 111. 